\title{
Satellite-derived phytoplankton biomass and production variability in 2 contrasting coastal areas: off southern California and off northern Baja California
}

\section{Variabilidad de la biomasa y la producción fitoplanctónicas, derivadas de satélite, en 2 áreas costeras contrastantes: frente al sur de California y frente al norte de Baja California}

\author{
Uriel Mirabal-Gómez ${ }^{1}$, Saúl Álvarez-Borrego ${ }^{2 *}$, José Rubén Lara-Lara \\ División de Oceanología, Centro de Investigación Científica y de Educación Superior de Ensenada, B.C., \\ Carretera Ensenada-Tijuana, no. 3918, Zona Playitas, CP 22860, Ensenada, Baja California, México. ${ }^{1}$ ORCID \\ iD 0000-0002-7087-5385, ${ }^{2}$ ORCID iD 0000-0002-7586-8678. \\ * Corresponding author. E-mail: alvarezb@cicese.mx.
}

\begin{abstract}
In order to compare phytoplankton biomass (satellite-derived chlorophyll, $\mathrm{Chl}_{\text {sat }}$ ) and production (PP), and sea surface temperature (SST) between the regions north and south of the Ensenada Front, time series were generated from satellite imagery for 250-km transects perpendicular to the coast: one off La Jolla (TLJ), southern California (USA), and the other off San Quintín Bay (TSQB), Baja California


used for the 2002-2016 period. An "average year" was generated for each transect and each variable as an approximation to the climatology. Data show spatial variation in $\mathrm{Chl}_{\text {sat }}$ and PP with higher values in the coastal zone $\left(>10.0 \mathrm{mg} \cdot \mathrm{m}^{-3}\right.$ and $>4.0 \mathrm{~g} \mathrm{C} \cdot \mathrm{m}^{-2} \cdot \mathrm{d}^{-1}$, respectively) than offshore $\left(\sim 0.1 \mathrm{mg} \cdot \mathrm{m}^{-3}\right.$ and $0.4 \mathrm{~g} \mathrm{C} \cdot \mathrm{m}^{-2} \cdot \mathrm{d}^{-1}$, respectively), while SST showed, in general, minimum values in the coastal zone $\left(\sim 15.0^{\circ} \mathrm{C}\right)$ and maxima offshore $\left(21.0^{\circ} \mathrm{C}\right)$. In the coastal zone, $\mathrm{Chl}_{\text {sat }}$ values were higher on TSQB than on TLJ. However, sometimes phytoplankton biomass was higher in the offshore waters of TLJ than in the offshore waters of TSQB because of the effect of high Chl sat plumes coming from Point

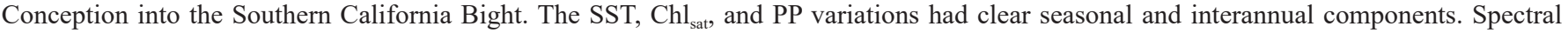
analysis shows that the seasonal component of variation was dominant for the 3 variables. The 2004 central Pacific type of El Niño, the 2014 "Blob", and the 2015-2016 eastern Pacific type of El Niño had very strong effects on phytoplankton biomass and production along both transects. Nevertheless, the effects generally tended to be stronger at TLJ than at TSQB. There are spatial variations in the coastal dynamics of the California Current System, and thus the effects of seasonal and interannual events will not be the same at different geographic locations.
\end{abstract}

Key words: Ensenada Front, phytoplankton biomass and production, sea surface temperature, seasonal and interannual variations.

RESUMEN. Se generaron series de tiempo de imágenes satelitales para 2 transectos de $250 \mathrm{~km}$ perpendiculares a la costa, uno frente a La Jolla (TLJ), California (EUA), y otro frente a la bahía San Quintín (TBSQ), Baja California (México), para comparar la biomasa (clorofila derivada de sátelite, $\mathrm{Chl}_{\mathrm{sat}}$ ) y producción fitoplanctónicas (PP) y la temperatura superficial del mar (TSM) entre las regiones al sur y al norte del Frente Ensenada. Se utilizaron composiciones mensuales de TSM y $\mathrm{Chl}_{\mathrm{sat}}$ del sensor Moderate Resolution Imaging Spectroradiometer (MODIS), y de PP para 2002-2016. Se generó un "año promedio" para cada transecto y cada variable como aproximación a la climatología. Los datos mostraron que $\mathrm{Chl}_{\text {sat }}$ y PP fueron mayores en la zona costera $\left(>10.0 \mathrm{mg} \cdot \mathrm{m}^{-3} \mathrm{y}>4.0 \mathrm{~g} \mathrm{C} \cdot \mathrm{m}^{-2} \cdot \mathrm{d}^{-1}\right.$, respectivamente) que en la oceánica $\left(\sim 0.1 \mathrm{mg} \cdot \mathrm{m}^{-3}\right.$ y $0.4 \mathrm{~g} \mathrm{C} \cdot \mathrm{m}^{-2} \cdot \mathrm{d}^{-1}$, respectivamente), mientras que la TSM presentó, en general, valores mínimos en la zona costera $\left(\sim 15.0{ }^{\circ} \mathrm{C}\right)$ y máximos mar adentro $\left(\sim 21.0^{\circ} \mathrm{C}\right)$. En la zona costera los valores de $\mathrm{Chl}_{\text {sat }}$ fueron más altos en TBSQ que en TLJ. Sin embargo, algunas veces la biomasa fitoplanctónica fue más alta en la zona oceánica de TLJ que en la de TBSQ debido al efecto de lengüetas de Ch1 ${ }_{\text {sat }}$ alta fluyendo de punta Concepción hacia la ensenada del sur de California. Las variaciones de la TSM, Chl $1_{\text {sat }}$ y PP tuvieron componentes estacionales e interanuales claros. El análisis espectral mostró que el componente estacional fue dominante para las 3 variables. El Niño de 2004 del tipo Pacífico central, el "Blob" de 2014 y El Niño de 2015-2016 del tipo Pacífico oriental tuvieron efectos muy fuertes en la biomasa y producción fitoplanctónicas en ambos transectos. Sin embargo, en general, hubo una tendencia a que los efectos fuesen más fuertes en TLJ que en TBSQ. La dinámica costera del Sistema de la Corriente de California tiene variaciones espaciales, y esto hace que los impactos de eventos estacionales e interanuales sean diferentes en las diversas localidades geográficas.

Palabras clave: Frente Ensenada, biomasa y producción fitoplanctónicas, temperatura superficial del mar, variaciones estacionales e interanuales.

\section{INTRODUCTION}

A variety of physical processes in the California Current System (CCS), such as coastal upwelling, jets, and eddies, contribute to the spatial and temporal variations of

\section{INTRODUCCIÓN}

En el Sistema de la Corriente de California (SCC) ocurren varios procesos físicos tales como surgencias costeras, chorros y remolinos que contribuyen a la variabilidad espacial 
phytoplankton biomass (chlorophyll, Chl) and production (PP) because they input nutrients to the euphotic zone (Lynn 1967, Pérez-Brunius et al. 2007). In spring there is reduced eddy activity in the CCS. During the rest of the year there are eddies and meanders, although with a predominant southward flux (Durazo et al. 2010). Eutrophic conditions are generally limited to a coastal band, associated with upwelling events, mainly during the months of winter and spring in the southern part of the CCS and during late spring and summer in the northern part (Fargion et al. 1993). Lynn and Simpson (1987) defined 3 domains in the CCS: an oceanic domain, a coastal domain, and a transition zone $200-300 \mathrm{~km}$ offshore that is parallel to the coast and coincides with the CCS core. Equatorial Water penetrates through the southern limit of the CCS in the form of a subsurface countercurrent near the coast (200 m depth, Lynn and Simpson 1987). At the end of autumn and beginning of winter there is a poleward surface flux in the narrow coastal zone, off the Baja California Peninsula and southern California. This flux is known as the surface coastal countercurrent, commonly known as the Davidson Current (Lynn and Simpson 1987, Reid 1988). There is evidence that this surface and subsurface countercurrents are independent phenomena (Durazo 2015).

The CCS is influenced by El Niño events, which are associated with an increase in sea surface temperature (SST) and a decrease in Chl and PP (Reid 1962, 1988; Putt and Prézelin 1985; Torres-Moye and Álvarez-Borrego 1987; Fargion 1989; Thomas and Strub 1990; Lynn et al. 1998; Kahru and Mitchell 2000, 2002). Events with anomalously low SSTs (La Niña) are associated with relatively high $\mathrm{Chl}$ and PP in this area (Kahru and Mitchell 2002). Furthermore, there was a recent anomalous warming of the north Pacific (known by the nickname "Blob"). This phenomenon was detected for the first time in autumn 2013 (Bond et al. 2015), and its effect off southern California and off northern Baja California ended by the end of November 2015 (NOAA 2017a). The Blob was a marine heat wave that produced major disturbances in the California Current ecosystem with great negative economic impacts (Gentemann 2017). It was strongly present off northwestern Baja California (Mexico), with SST values for October 2014 approximately $6^{\circ} \mathrm{C}$ above the maximum temperatures of other years in the period 2008-2014; these values were measured from an anchored buoy in coastal waters off Ensenada, Baja California (Coronado-Álvarez et al. 2017).

Off Ensenada there is a change in the direction of the surface geostrophic flow towards the coast (Reid 1988). This forms the Ensenada Front, which is perpendicular to the coast and extends from 160 to $500 \mathrm{~km}$ offshore. In the offshore area, this frontal region separates eutrophic colder waters in the north from the oligotrophic waters in the south, and the frontal structure persists throughout the year (Peláez and McGowan 1986, Gaxiola-Castro and Álvarez-Borrego 1991, Haury et al. 1993). The front is detectable during most of the year but it is strong from the end of March to the beginning of June, and it shows a latitudinal displacement of $\sim 150 \mathrm{~km}$ throughout the whole y temporal de la biomasa (clorofila, Chl) y producción (PP) del fitoplancton, ya que aportan nutrientes a la zona eufótica (Lynn 1967, Pérez-Brunius et al. 2007). Durante la primavera la actividad de remolinos es reducida en el SCC. Durante el resto del año se observan giros y meandros, aunque con un flujo predominante hacia el sur (Durazo et al. 2010). Las condiciones eutróficas generalmente se limitan a una franja costera, asociada con los eventos de surgencia, especialmente durante los primeros meses del año (invierno y primavera) en la parte sur del SCC y durante finales de primavera y verano en la parte norte (Fargion et al. 1993). Lynn y Simpson (1987) definieron 3 dominios para el SCC: el oceánico, el costero y una zona de transición 200-300 km mar adentro que se encuentra paralela a la costa y que coincide con el núcleo del SCC. La masa de Agua Ecuatorial penetra a través del límite sur del SCC en la forma de una contracorriente subsuperficial cercana a la costa (200 m de profundidad, Lynn y Simpson 1987). A finales de otoño y principios de invierno, hay un flujo superficial hacia el polo en la zona costera estrecha frente a la península de Baja California y el sur de California (Lynn y Simpson 1987). Este flujo es conocido como contracorriente superficial costera, y también es comúnmente conocido como corriente de Davidson (Lynn y Simpson 1987, Reid 1988). Hay evidencia de que estas contracorrientes, tanto la superficial como la subsuperficial, son fenómenos independientes (Durazo 2015).

El SCC es influenciado por eventos El Niño asociados a incrementos de la temperatura superficial del mar (TSM) y a decrementos de la Chl y la PP (Reid 1962, 1988; Putt y Prézelin 1985; Torres-Moye y Álvarez-Borrego 1987; Fargion 1989; Thomas y Strub 1990; Lynn et al.1998; Kahru y Mitchell 2000, 2002). Los eventos con TSM anómalamente bajas (La Niña) están asociados con Chl y PP relativamente altas en esta área (Kahru y Mitchell 2002). Además, recientemente, se presentó un fenómeno de calentamiento anómalo en el Pacífico norte (denominado con el apodo en inglés "Blob"). Este fenómeno se detectó por primera vez en otoño de 2013 (Bond et al. 2015), y su efecto frente al sur de California y norte de Baja California terminó hacia el final de noviembre de 2015 (NOAA 2017a). El Blob fue una onda marina de calor que produjo disturbios grandes en el ecosistema de la corriente de California con grandes impactos económicos negativos (Gentemann 2017). La presencia del Blob frente al noroeste de Baja California (México) fue muy fuerte, con valores de TSM para octubre de 2014 de $\sim 6{ }^{\circ} \mathrm{C}$ por encima de los máximos para otros años en el periodo 2008-2014; estos valores fueron medidos desde una boya anclada en aguas costeras frente a Ensenada, Baja California (Coronado-Álvarez et al. 2017).

Frente a Ensenada hay un cambio en la dirección del flujo geostrófico superficial del mar abierto hacia la costa (Reid 1988). Esto forma el Frente Ensenada, que se presenta perpendicular a la costa y se extiende de 160 a $500 \mathrm{~km}$ de la costa. En la zona oceánica, esta región frontal separa las aguas eutróficas y más frías del norte de las aguas oligotróficas del 
year (Peláez and McGowan 1986). Moreover, the position of the front is affected by El Niño/Southern Oscillation (ENSO) events (Santamaría-del-Ángel et al. 2002). When this surface geostrophic flux reaches the coast, it splits into two: one flux flows northward into the cyclonic circulation of the Southern California Bight and the other flows southward (Peláez and McGowan 1986). The latter flux turns offshore off San Quintín Bay, similar to the offshore flux off Point Conception, California (USA). These fluxes that veer from the coast intensify coastal upwelling (Álvarez-Borrego 2004).

The main objective of this work was to characterize the spatial and temporal variations of $\mathrm{Chl}$ and PP off La Jolla, California, and off San Quintín Bay, Baja California, (Fig. 1) to compare 2 different oceanographic conditions given their geographic positions with respect to the Ensenada Front. The study used data generated by a satellite sensor, covering the seasonal and interannual scales; emphasis was made on the effect of physical processes such as upwelling, El Niño, and the Blob.

\section{MATERIALS AND METHODS}

\section{Study areas}

The area off La Jolla is inside the cyclonic eddy of the Southern California Bight (SCB). In the SCB there are relatively weak, upwelling-favorable winds compared with other regions along the CCS, and the maximum wind stress axis is

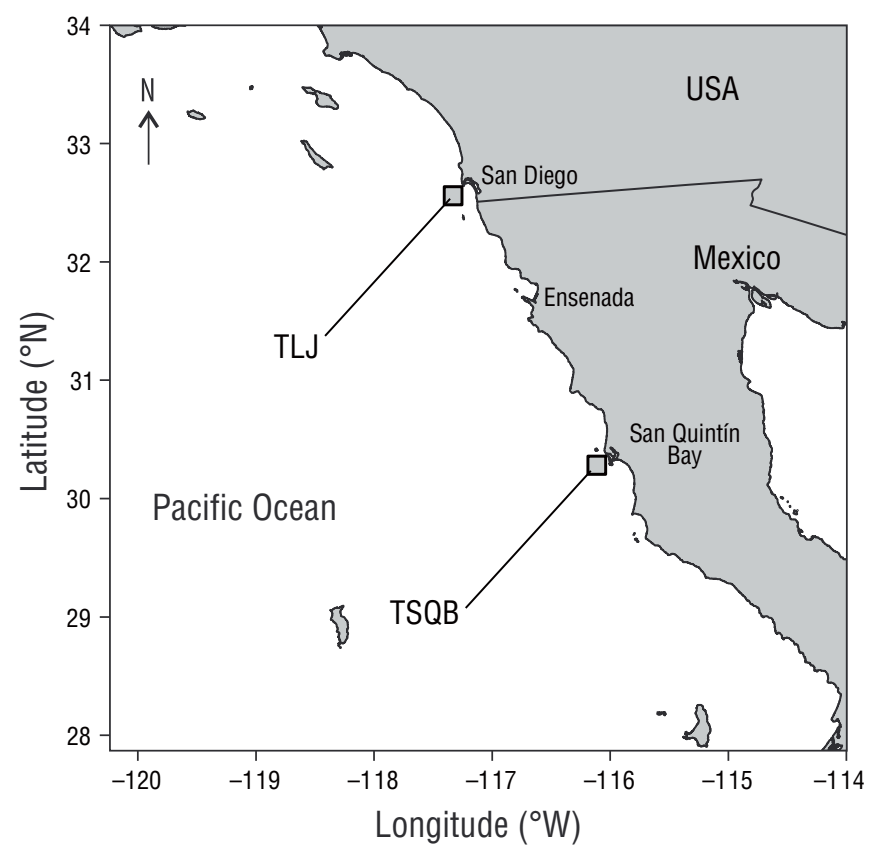

Figure 1. Transects and quadrants off La Jolla (TLJ) and San Quintín Bay (TSQB).

Figura 1. Transectos y cuadrantes frente a La Jolla (TLJ) y bahía San Quintín (TSQB). sur, y la estructura frontal persiste a lo largo del año (Peláez y McGowan 1986, Gaxiola-Castro y Álvarez-Borrego 1991, Haury et al. 1993). El frente es detectable durante la mayor parte del año, pero es fuerte desde finales de marzo hasta principios de junio; además, muestra un desplazamiento latitudinal de $\sim 150 \mathrm{~km}$ a lo largo de todo el año (Peláez y McGowan 1986). La posición del frente es afectada por eventos de El Niño/Oscilación del Sur (ENOS) (Santamaría-del-Ángel et al. 2002). Al toparse con la línea de costa, este flujo geostrófico superficial se divide en dos: uno se dirige hacia el norte y entra al giro ciclónico de la ensenada del Sur de California, y otro se dirige hacia el sur (Peláez y McGowan 1986). Este último flujo hace un cambio de dirección hacia mar adentro frente a la bahía San Quintín, de una manera similar a como lo hace el flujo que se aleja de la costa frente a punta Concepción, California (EUA). Estos flujos hacia mar abierto intensifican las surgencias (Álvarez-Borrego 2004).

El objetivo principal de esta investigación fue caracterizar la variabilidad espacial y temporal de la Chl y PP frente a La Jolla, California, y frente a bahía San Quintín, Baja California, (Fig. 1) para comparar 2 condiciones oceanográficas diferentes por su posición con respecto al Frente Ensenada. El análisis se llevó a cabo con información generada por un sensor de satélite y cubrió las escalas estacional e interanual; se hizo énfasis en procesos físicos como surgencias, El Niño y el Blob.

\section{MATERIALES Y MÉTODOS}

\section{Áreas de estudio}

El área frente a La Jolla está dentro del giro ciclónico de la ensenada del sur de California (ESC). En la ESC hay vientos favorables a las surgencias que son relativamente débiles comparados con los vientos en otras regiones del SCC y el eje del máximo estrés del viento está más alejado de la línea de costa; las velocidades de los vientos en la ESC son más bajas que las de los vientos $140 \mathrm{~km}$ mar adentro por un factor de 2 o más (Dorman 1982, Winant y Dorman 1997). Hay un flujo fuerte hacia el polo en la zona costera, principalmente en otoño e invierno. Este flujo se debilita en la primavera. Al sur de punta Concepción, el flujo es un remolino ciclónico grande sobre los bancos localizados mar adentro en la ESC (Lynn y Simpson 1987). El flujo atmosférico se separa de la costa cerca de punta Concepción y se produce un remolino grande de cizallamiento del viento con un bombeo de Ekman promedio de $4 \mathrm{~m} \cdot \mathrm{d}^{-1}$, que con vientos fuertes persistentes puede alcanzar $20 \mathrm{~m} \cdot \mathrm{d}^{-1}$ (Münchow 2000).

$\mathrm{La} \mathrm{Chl}$ de la capa superior, medida en muestras de agua y por sensores remotos, tiene una variación estacional significativa en la ESC y es más alta a mediados y finales de invierno y más baja en verano (Eppley et al. 1985, Michaelsen et al. 1988). La integral de Chl (0-150 m) de la ESC, en la línea 90 de CalCOFI (California Cooperative Oceanic Fisheries Investigations), mostró una señal estacional débil, con la media de 
further away from the coastline; wind speeds in the SCB are lower than wind speeds $140 \mathrm{~km}$ offshore by a factor of 2 or more (Dorman 1982, Winant and Dorman 1997). There is a strong poleward flow in the coastal zone, mainly in autumn and winter. This poleward flow weakens in spring. South of Point Conception, this flow appears as a large cyclonic eddy over the SCB offshore banks (Lynn and Simpson 1987). The atmospheric flow separates from the coast near Point Conception, producing a large wind stress curl with an average Ekman pumping of $4 \mathrm{~m} \cdot \mathrm{d}^{-1}$, and with strong persistent winds this pumping may reach $20 \mathrm{~m} \cdot \mathrm{d}^{-1}$ (Münchow 2000).

Upper layer Chl, both measured from water samples and by remote sensing, exhibits significant seasonal variation in the SCB, and it is highest in mid and late winter and lowest in summer (Eppley et al. 1985, Michaelsen et al. 1988). Integrated $(0-150 \mathrm{~m}) \mathrm{Chl}$ in the SCB, within CalCOFI (California Cooperative Oceanic Fisheries Investigations) line 90, showed a weak seasonal signal, with the April-May mean well above the overall mean; but the monthly bight-wide, space averaged, integrated $\mathrm{Chl}$, and the surface, space averaged $\mathrm{Chl}$ did not show a seasonal pattern (Fargion et al. 1993). There is a clear onshore-offshore gradient in all seasons for surface $\mathrm{Chl}$ to be higher in the coastal zone than in the offshore zone of the SCB (Fargion et al. 1993).

The area off San Quintín Bay is characterized by high $\mathrm{Chl}$ and PP because of intense upwelling (Lara-Lara et al. 1980, Álvarez-Borrego and Álvarez-Borrego 1982, MillánNúñez et al. 1982). In the open ocean, near the mouth of San Quintín Bay, upwelling events occur from April to October, with the most intense during spring and summer as a result of the dominance of northwesterly winds (Álvarez-Borrego and Álvarez-Borrego 1982) and the coastal circulation induced by the Ensenada Front (Álvarez-Borrego 2004). Off San Quintín Bay circulation has 2 components: one is parallel to the coast and has an equatorward direction, and the other is offshore to compensate the onshore component of transport at the Ensenada Front (Álvarez-Borrego 2004).

\section{Satellite data}

Monthly composites of SST and $\mathrm{Ch}_{\mathrm{sat}}$ from the Moderate Resolution Imaging Spectroradiometer aboard the Aqua satellite (Aqua-MODIS) for the July 2002-December 2016 period were used to generate the time series. These composites were obtained from the National Aeronautics and Space Administration (NASA) Ocean Color web page (NASA 2017), with level 3 and $9 \times 9 \mathrm{~km}^{2}$ pixel size. The SST data are from day measurements with $11 \mu \mathrm{m}$ radiation. All PP imagery were obtained from the Ocean Net Primary Productivity website of the Oregon State University (OSU 2017). Images were downloaded in Hierarchical Data Format (.hdr format). Phytoplankton production is given as a standard product already calculated using the Behrenfeld and Falkowsky (1997) vertically generalized productivity model (VGPM). The VGPM is a non-spectral model with homogeneous vertical distribution abril-mayo por encima de la media general; sin embargo, el promedio mensual de la Chl integrada, promediada espacialmente a todo lo ancho de la ESC y la Chl superficial promediada espacialmente no mostraron un patrón estacional (Fargion et al. 1993). Durante todo el año, hay un gradiente en la ESC, de la costa hacia mar adentro, con Chl mayor en la zona costera que en mar adentro (Fargion et al. 1993).

La zona frente a la bahía San Quintín se caracteriza por su alta Chl y PP debido a las surgencias intensas (Lara-Lara et al. 1980, Álvarez-Borrego y Álvarez-Borrego 1982, MillánNúñez et al. 1982). En mar abierto, en la región cercana a la boca de la bahía San Quintín, los eventos de surgencia ocurren de abril a octubre, y los más intensos ocurren en primavera y verano como resultado del dominio de los vientos del noroeste (Álvarez-Borrego y Álvarez-Borrego 1982) y la circulación costera inducida por el Frente Ensenada (Álvarez-Borrego 2004). Frente a la bahía San Quintín, la circulación oceánica presenta 2 componentes, uno paralelo a la costa y hacia el ecuador y el otro hacia mar adentro para compensar parcialmente el transporte hacia la costa que se da en el Frente Ensenada (Álvarez-Borrego 2004).

\section{Datos de satélite}

Las series de tiempo se generaron a partir de composicio-

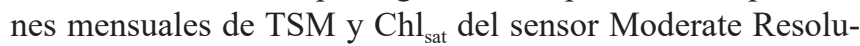
tion Imaging Spectroradiometer (Aqua-MODIS), del periodo julio 2002-diciembre 2016. Las composiciones mensuales se descargaron de la página de internet del "Ocean Color" (por su nombre en inglés) de la Administración Nacional de la Aeronáutica y del Espacio (NASA) (NASA 2017), con una resolución de $9 \times 9 \mathrm{~km}^{2}$ y nivel 3 de procesamiento. Los datos de TSM son mediciones de día con radiación de $11 \mu \mathrm{m}$ de longitud de onda. Los datos de PP se descargaron de la página de la Universidad Estatal de Oregón (OSU 2017). Las imágenes fueron descargadas en el formato Hierarchical Data Format (.hdr). La PP es proporcionada como un producto estándar que ya está calculado usando el modelo generalizado de producción verticalmente integrada (VGPM, por sus siglas en inglés) de Behrenfeld y Falkowsky (1997). El VGPM es un modelo no espectral con distribución vertical homogénea de Chl y con producción integrada con la profundidad. Los pixeles de PP fueron de $18 \times 18 \mathrm{~km}^{2}$. Las imágenes de satélite se procesaron con programática obtenida del sitio de internet del "Ocean Color" de la NASA (NASA 2017).

Para describir la variación espacial y temporal de TSM, $\mathrm{Chl}_{\text {sat }}$ y PP, se muestrearon 2 transectos de $250 \mathrm{~km}$, perpendiculares a la costa (Fig. 1), de las composiciones mensuales: uno frente a La Jolla (TLJ) y otro frente a la bahía San Quintín (TBSQ). Describimos una primera aproximación a la climatología de la región con base en un "año promedio" para cada variable y para cada transecto. Este año promedio consiste en promediar los datos de enero de todos los años, luego los datos de febrero, y así sucesivamente para todos los meses. Para describir la variación temporal con más detalle 
of $\mathrm{Chl}$ and with vertically integrated PP. Pixel size for PP was $18 \times 18 \mathrm{~km}^{2}$. Satellite imagery was processed with software from the NASA Ocean Color web page (NASA 2017).

Two $250-\mathrm{km}$ long transects perpendicular to the coast (Fig. 1), one off La Jolla (TLJ) and the other off San Quintín Bay (TSQB), were sampled from the monthly composites to describe the spatial and temporal variations of SST, $\mathrm{Chl}_{\text {sat }}$ and PP. We described a first approximation to the climatology of the region based on an "average year" for each variable and for each transect. This climatology consisted in averaging data for the Januaries of all years, then data for all Februaries, and so on for all months. In order to describe the temporal variation in more detail, we generated time series with the monthly averages of the variables from an $18 \times 18 \mathrm{~km}^{2}$ coastal quadrant off La Jolla (centered at $31.66^{\circ} \mathrm{N}, 116.99^{\circ} \mathrm{W}$ ) and another one off San Quintín Bay (centered at $30.66^{\circ} \mathrm{N}$, $116.33^{\circ} \mathrm{W}$ ) (Fig. 1), from July 2002 through December 2016. Matlab 2014b was used for the spectral analysis of the time series in order to characterize the relative magnitude of the different components of variation.

STATISTICA v.7.0.2 software was used for the statistical analysis. $\mathrm{Chl}_{\text {sat }}$ distributions were not normal. Each year was divided into 2 seasons and each transect into 2 zones (one inshore zone and one offshore zone). Thus, non-parametric Mann-Whitney tests were performed to explore $\mathrm{Chl}_{\text {sat }}$ differences between the 2 seasons for each zone on each transect, between the 2 zones on each transect, and between transects. Matlab 2014b was used to build Hovmöller diagrams with SST and $\mathrm{Ch}_{\text {sat }}$ data from all years.

The Multivariate El Niño Index (NOAA 2017b) was used to distinguish between El Niño, La Niña, and "normal" conditions.

\section{RESULTS}

In general, the average year showed very clear variations in $\mathrm{Chl}_{\text {sat }}$ and PP between inshore and offshore areas, with higher values in the zone near the coast. On the other hand, SST showed a different spatial variation, with lower values near the coast than offshore on both transects but mainly on TSQB. On TLJ the SST gradient was inverted in July and August, with higher values near the coast than offshore. In June SST variations were irregular for both transects (Fig. 2).

Throughout the average year, the SST differences from near the coast to further offshore ranged from a few tenths of a degree to $\sim 5.7^{\circ} \mathrm{C}$ on TLJ. The maximum SST value $\left(20.8^{\circ} \mathrm{C}\right)$ for this transect occurred in September at $\sim 50 \mathrm{~km}$ from shore, whereas the minima $\left(\sim 15.2^{\circ} \mathrm{C}\right)$ occurred in January, February, and March near the coast. On this transect, SST showed almost no spatial variations in May, fluctuating a few tenths of a degree around $17^{\circ} \mathrm{C}$. For TSQB the SST spatial differences ranged from a few tenths of a degree to $\sim 6.7^{\circ} \mathrm{C}$ throughout the average year. The maximum SST value $\left(\sim 21.2^{\circ} \mathrm{C}\right)$ for this transect also occurred in September, and minima $\left(\sim 14.7^{\circ} \mathrm{C}\right)$ occurred in February, March, and April. se generaron series de tiempo de los promedios mensuales de las variables en un cuadro costero de $18 \times 18 \mathrm{~km}^{2}$ frente a La Jolla (centrado en $31.66^{\circ} \mathrm{N}, 116.99^{\circ} \mathrm{W}$ ) y otro frente a la bahía San Quintín (centrado en $30.66^{\circ} \mathrm{N}, 116.33^{\circ} \mathrm{W}$ ) (Fig. 1), de julio de 2002 a diciembre de 2016. Se utilizó Matlab 2014b para el análisis espectral de estas series de tiempo para caracterizar la magnitud relativa de los diferentes componentes de variación.

Para el análisis estadístico, se utilizó la programática STATISTICA v.7.0.2. Las distribuciones de $\mathrm{Ch}_{\text {sat }}$ no fueron normales. Los años se dividieron en 2 temporadas, y cada transecto se dividió en 2 zonas (una costera y una oceánica). Por lo tanto, se hicieron pruebas no paramétricas de Mann-Whitney para explorar diferencias de $\mathrm{Chl}_{\text {sat }}$ entre las 2 temporadas de cada zona en cada transecto, entre las 2 zonas de cada transecto y entre transectos. También se utilizó Matlab 2014b para construir diagramas Hovmöller con los datos de TSM y $\mathrm{Chl}_{\text {sat }}$ de todos los años.

El Índice Multivariado de El Niño (NOAA 2017b) se utilizó para distinguir entre eventos El Niño, La Niña y "condiciones normales."

\section{Resultados}

En general, el año promedio presentó una variación espacial muy clara de $\mathrm{Chl}_{\text {sat }}$ y PP de la costa hacia mar adentro, y los valores más altos ocurrieron en la zona cercana a la costa. Por otro lado, la TSM mostró una variación espacial diferente, puesto que los valores fueron menores en la costa que en mar adentro en los 2 transectos, sobre todo en TBSQ. En TLJ se invirtió el gradiente de TSM en julio y agosto, pues los valores fueron más altos cerca de la costa que en mar adentro. En junio se presentaron variaciones irregulares de TSM en ambos transectos (Fig. 2).

A lo largo del año promedio, en TLJ, las diferencias de TSM desde cerca de la costa hasta mar adentro fueron desde unas pocas décimas de grado hasta $\sim 5.7^{\circ} \mathrm{C}$. El valor máximo de TSM $\left(20.8^{\circ} \mathrm{C}\right)$ para este transecto se presentó en septiembre a $\sim 50 \mathrm{~km}$ de la costa, mientras que los mínimos $\left(\sim 15.2^{\circ} \mathrm{C}\right)$ se presentaron en enero, febrero y marzo cerca de la costa. En este transecto, la TSM prácticamente no varió espacialmente en mayo, fluctuando pocas décimas de grado alrededor de $17^{\circ} \mathrm{C}$. En TBSQ, las diferencias espaciales de TSM fueron desde unas pocas décimas de grado hasta $\sim 6.7^{\circ} \mathrm{C}$ a lo largo del año promedio. En este transecto el valor máximo de TSM $\left(\sim 21.2^{\circ} \mathrm{C}\right)$ se presentó también en septiembre, mientras que los mínimos $\left(\sim 14.7^{\circ} \mathrm{C}\right)$ se presentaron en febrero, marzo y abril.

De acuerdo con la distribución espacial de $\mathrm{Chl}_{\text {sat }}$ del año promedio, se puede considerar que la zona costera se extiende desde la costa hasta $\sim 50 \mathrm{~km}$ en ambos transectos (Fig. 2) y la zona oceánica desde $\sim 50 \mathrm{~km}$ hacia mar adentro. En general, al considerar el valor de $2 \mathrm{mg} \cdot \mathrm{m}^{-3}$ como criterio para separar las aguas eutróficas de las aguas mesotróficas en la zona costera, la climatología de $\mathrm{Chl}_{\text {sat }}$ para ambos 
Ciencias Marinas, Vol. 43, No. 4, 2017

TLJ


Feb
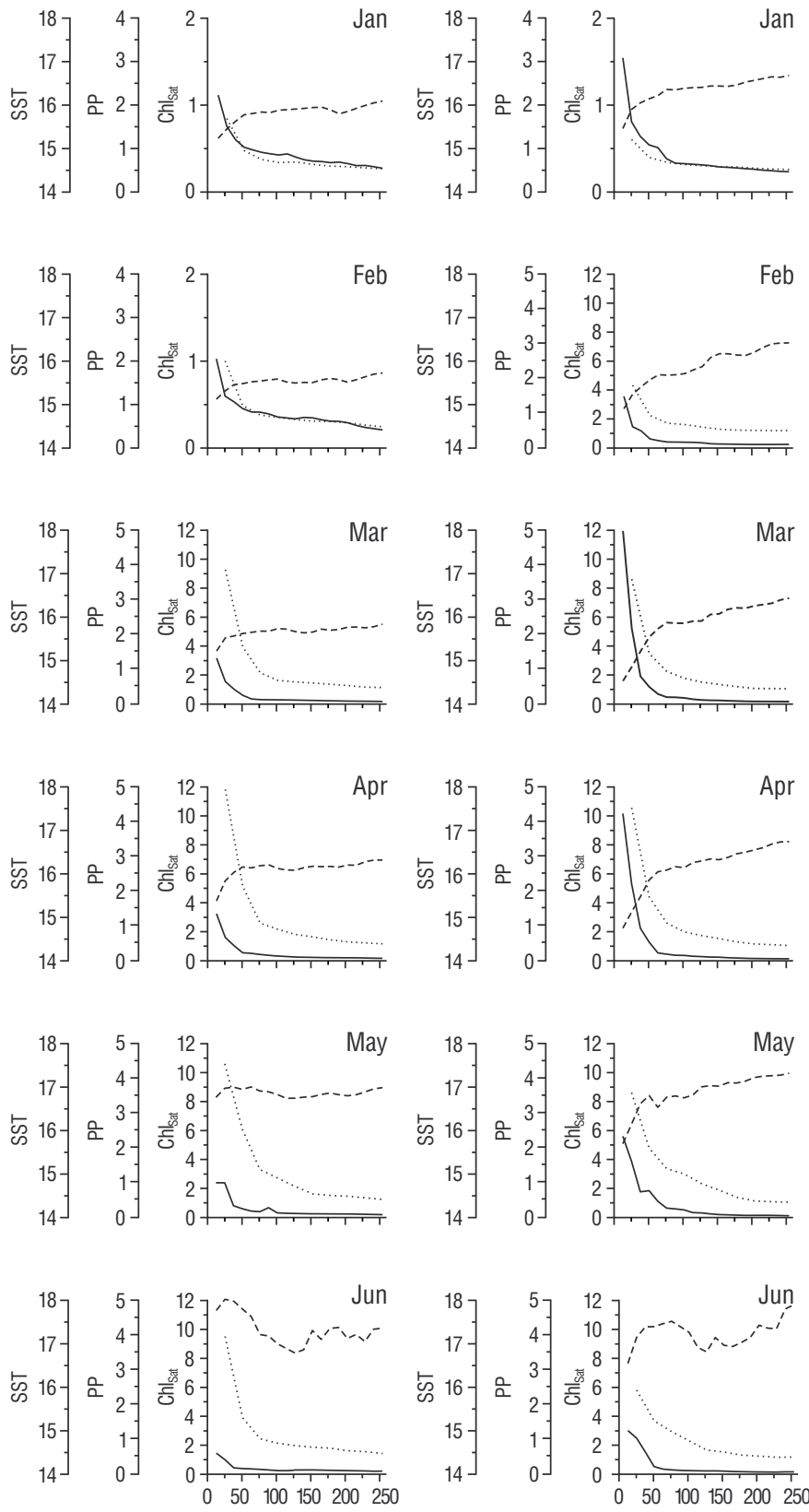

TLJ

TSQB
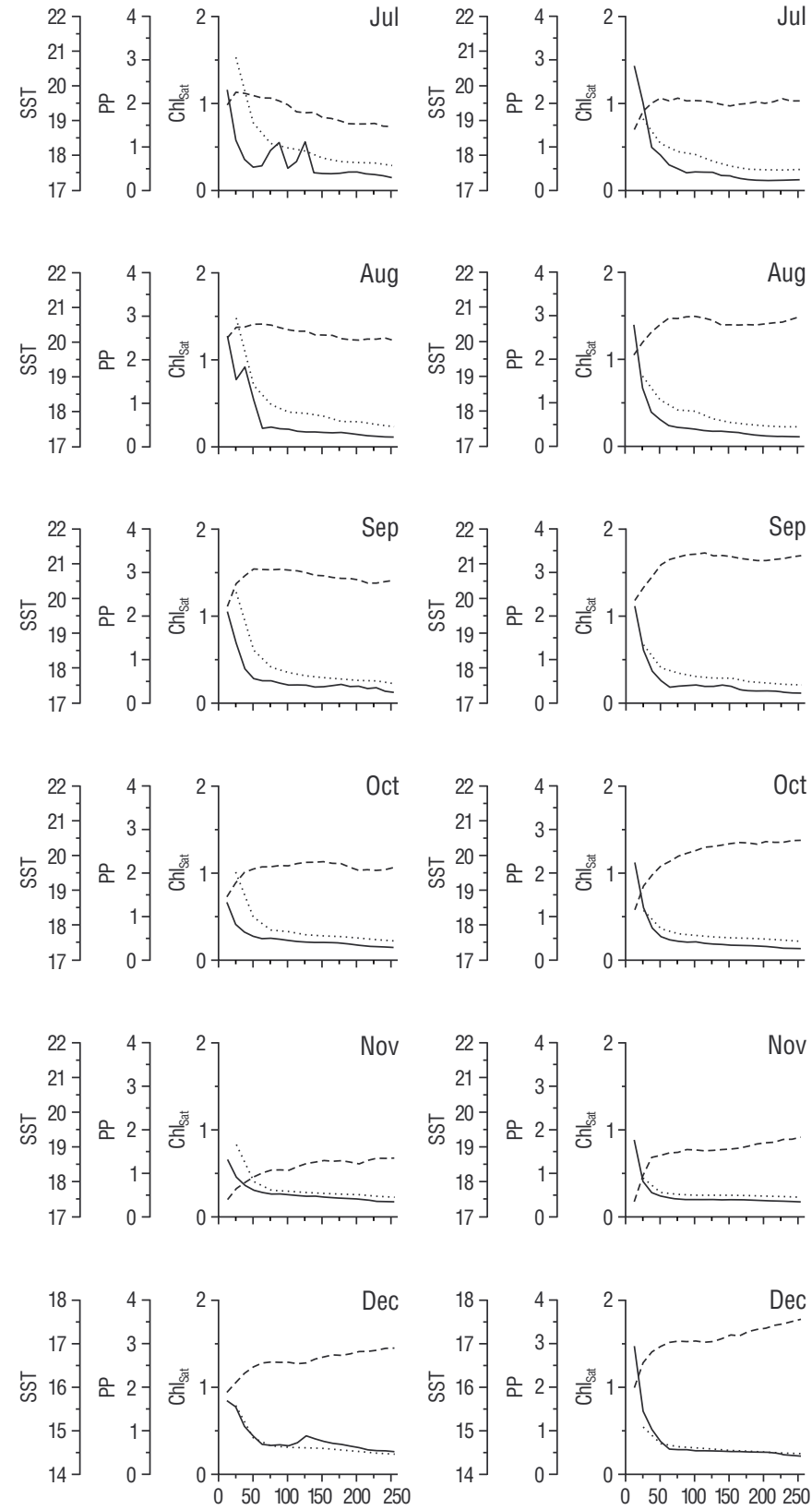

Distance $(\mathrm{km})$

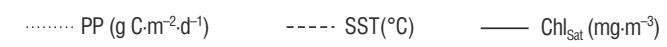

Figure 2. Climatology of the 3 variables for the transect off La Jolla (TLJ) (left panels) and the transect off San Quintín Bay (TSQB) (right panels).

Figura 2. Climatología de las 3 variables para el transecto frente a La Jolla (TLJ, paneles de la izquierda) y para el transecto frente a bahía San Quintín (TSQB, paneles de la derecha). 
Taking into account the spatial distribution of $\mathrm{Chl}_{\mathrm{sat}}$ for the average year, we may consider the inshore zone to extend seaward from the coast to $\sim 50 \mathrm{~km}$ for both transects (Fig. 2) and the offshore zone to extend from $\sim 50 \mathrm{~km}$ and beyond. In general, when taking the $2-\mathrm{mg} \cdot \mathrm{m}^{-3}$ value as a criterion to separate eutrophic waters from mesotrophic waters in the coastal zone, the $\mathrm{Chl}_{\text {sat }}$ climatology for both transects showed 2 seasons with different biological conditions. The first season for TLJ was from March to June, with the highest $\mathrm{Ch}_{\mathrm{sat}}$ value $\left(3.2 \mathrm{mg} \cdot \mathrm{m}^{-3}\right)$ occurring in April, and the first season for TSQB was from February to June, with the maximum Chl $\mathrm{Cat}_{\text {sat }}$ value $\left(11.9 \mathrm{mg} \cdot \mathrm{m}^{-3}\right)$ occurring in March. During the second season, maxima $\mathrm{Chl}_{\text {sat }}$ in the inshore zone were $1.3 \mathrm{mg} \cdot \mathrm{m}^{-3}$ (August) for TLJ and $1.5 \mathrm{mg} \cdot \mathrm{m}^{-3}$ (January) for TSQB. Throughout the average year the lowest value for both transects was $\sim 0.1 \mathrm{mg} \cdot \mathrm{m}^{-3}$ in the furthest offshore area (200 to $250 \mathrm{~km}$ ).

The PP plots for the average year were very similar to the $\mathrm{Chl}_{\mathrm{sat}}$ plots, with high values near the coast decreasing with distance from the coast (Fig. 2). In the coastal zone, the first season maxima occurred in April $\left(4.9 \mathrm{~g} \mathrm{C} \cdot \mathrm{m}^{-2} \cdot \mathrm{d}^{-1}\right.$ for TLJ and $4.3 \mathrm{~g} \mathrm{C} \cdot \mathrm{m}^{-2} \cdot \mathrm{d}^{-1}$ for TSQB) and those for the second season occurred in July $\left(3.0 \mathrm{~g} \mathrm{C} \cdot \mathrm{m}^{-2} \cdot \mathrm{d}^{-1}\right.$ for TLJ and $1.6 \mathrm{~g} \mathrm{C} \cdot \mathrm{m}^{-2} \cdot \mathrm{d}^{-1}$ for TSQB). For TLJ, PP minima were $\sim 0.5 \mathrm{~g} \mathrm{C} \cdot \mathrm{m}^{-2} \cdot \mathrm{d}^{-1}$ in the first season and $\sim 0.4 \mathrm{~g} \mathrm{C} \cdot \mathrm{m}^{-2} \cdot \mathrm{d}^{-1}$ in the second season, and both values were detected in the farthest offshore area. For TSQB, PP minima in both seasons were $0.4 \mathrm{~g} \mathrm{C} \cdot \mathrm{m}^{-2} \cdot \mathrm{d}^{-1}$ and occurred also in the farthest offshore area.

The month-to-month SST variation showed clear seasonal and interannual components for both transects. The SST spatial distribution on TLJ was irregular, with several minima and maxima in most months, although with a slight tendency to show the lowest values near the coast. On TSQB the SST spatial distribution was regular and monotonic, with lower values near the coast than offshore. During the study period the SST range for TLJ was $13.6-24.0^{\circ} \mathrm{C}$ in the inshore zone and $11.9-23.6^{\circ} \mathrm{C}$ in the offshore zone; for TSQB the range was $13.2-25.1^{\circ} \mathrm{C}$ in the inshore zone and $12.0-25.0^{\circ} \mathrm{C}$ in the offshore zone. The SST differences between both transects, for every month, were similar for both zones, exceptionally up to $1.2^{\circ} \mathrm{C}$ for the inshore zone and up to $2.3^{\circ} \mathrm{C}$ for the offshore zone, often with higher values in the TLJ inshore zone than in the TSQB inshore zone. Along both transects, SST minima occurred in winter-spring and SST maxima occurred in summer and the beginning of autumn (Table 1).

Hovmöller diagrams showed that on TLJ, even though minimum SST was detected in offshore waters in June 2010 (Table 1), waters along the entire transect were colder in the first seasons of 2007-2009 and 2011-2012 than in the other years of our study period. Conversely, 2015 showed higher SSTs than the rest of the years, although 2014 and 2016 were also relatively warm years (Fig. 3). A similar situation was observed for TSQB, with 2015 as the warmest year. Also on TSQB, there was a clear SST gradient with colder waters in the coastal zone than offshore during "normal" and warm transectos mostró 2 temporadas con condiciones biológicas diferentes. La primera temporada para TLJ fue de marzo a junio, y el valor más alto de $\mathrm{Chl}_{\mathrm{sat}}\left(3.2 \mathrm{mg} \cdot \mathrm{m}^{-3}\right)$ se presentó en abril; y la primera temporada para TBSQ fue de febrero a junio, y el valor máximo de $\mathrm{Chl}_{\mathrm{sat}}\left(11.9 \mathrm{mg} \cdot \mathrm{m}^{-3}\right)$ se presentó en marzo. En la segunda temporada los valores máximos de $\mathrm{Chl}_{\text {sat }}$ en la zona costera fueron $1.3 \mathrm{mg} \cdot \mathrm{m}^{-3}$ (agosto) para TLJ y $1.5 \mathrm{mg} \cdot \mathrm{m}^{-3}$ (enero) para TBSQ. En todo el año promedio, el valor más bajo para ambos transectos fue $\sim 0.1 \mathrm{mg} \cdot \mathrm{m}^{-3} \mathrm{y}$ se presentó en la zona más oceánica (200 a $250 \mathrm{~km})$.

Las curvas del año promedio de PP fueron muy similares a las de $\mathrm{Chl}_{\text {sat, }}$ ya que en ambos casos los valores altos se ubicaron cerca de la costa y disminuyeron hacia mar adentro (Fig. 2). En la zona costera los máximos de la primera temporada se presentaron en abril $\left(4.9 \mathrm{~g} \mathrm{C} \cdot \mathrm{m}^{-2} \cdot \mathrm{d}^{-1}\right.$ para TLJ y $4.3 \mathrm{~g} \mathrm{C} \cdot \mathrm{m}^{-2} \cdot \mathrm{d}^{-1}$ para TBSQ) y los de la segunda temporada en julio $\left(3.0 \mathrm{~g} \mathrm{C} \cdot \mathrm{m}^{-2} \cdot \mathrm{d}^{-1}\right.$ para TLJ y $1.6 \mathrm{~g} \mathrm{C} \cdot \mathrm{m}^{-2} \cdot \mathrm{d}^{-1}$ para TBSQ). Los mínimos de PP en TLJ fueron $\sim 0.5 \mathrm{~g} \mathrm{C} \cdot \mathrm{m}^{-2} \cdot \mathrm{d}^{-1}$ para la primera temporada y $\sim 0.4 \mathrm{~g} \mathrm{C} \cdot \mathrm{m}^{-2} \cdot \mathrm{d}^{-1}$ para la segunda temporada, y se presentaron en la zona más alejada de la costa. El valor mínimo de PP en TBSQ, en ambas temporadas, fue $0.4 \mathrm{~g} \mathrm{C} \cdot \mathrm{m}^{-2} \cdot \mathrm{d}^{-1} \mathrm{y}$ también se presentó en la zona más alejada de la costa.

La variación de TSM de mes a mes en el periodo estudiado (2002-2016) mostró componentes estacionales e interanuales claros para ambos transectos. La distribución espacial de TSM en TLJ fue irregular, con varios mínimos y máximos en la mayoría de los meses, aunque con cierta tendencia a mostrar los valores más bajos cerca de la costa. En TBSQ, la distribución espacial de TSM fue regular y monotónica, con valores más bajos cerca de la costa que en la zona oceánica. Para el periodo de estudio, el rango de TSM para TLJ fue de 13.6 a $24.0{ }^{\circ} \mathrm{C}$ en la zona costera y de 11.9 a $23.6^{\circ} \mathrm{C}$ en la zona oceánica; para TBSQ, el rango fue de 13.2 a $25.1^{\circ} \mathrm{C}$ en la zona costera y de 12.0 a $25.0^{\circ} \mathrm{C}$ en la oceánica. Las diferencias de TSM entre ambos transectos, para cada mes, fueron similares en las 2 zonas, excepcionalmente de hasta $1.2^{\circ} \mathrm{C}$ en la zona costera y hasta $2.3^{\circ} \mathrm{C}$ en la zona oceánica, aunque en la zona costera de TLJ a menudo se presentaron valores más altos que en TBSQ. A lo largo de ambos transectos, la TSM mínima se manifestó en invierno y primavera y la TSM máxima en verano y principios de otoño (Tabla 1 ).

Los diagramas Hovmöller mostraron que en TLJ, a pesar de que el mínimo de TSM sucedió en las aguas oceánicas en junio de 2010 (Tabla 1), las aguas en todo el transecto fueron más frías en la primera temporada de 2007-2009 y 2011-2012 que en los otros años de nuestro periodo de estudio. Por otra parte, 2015 presentó las TSM más altas que el resto de los años aunque 2014 y 2016 también fueron años relativamente cálidos (Fig. 3). En el caso de TBSQ, hubo una situación similar, ya que 2015 también representó el año más cálido. Además, en TBSQ hubo un gradiente claro de TSM durante la primera temporada, en el cual las aguas fueron más frías en la zona costera que en la oceánica en años "normales" y cálidos. Este gradiente no fue claro en los años fríos del 
Table 1. Sea surface temperature $\left(\mathrm{SST},{ }^{\circ} \mathrm{C}\right)$ minima and maxima, and the month on which they occurred, for the inshore $(0$ to $50 \mathrm{~km})$ and offshore zones on the transect off La Jolla (TLJ) and the transect off San Quintín Bay (TSQB) in each year.

Tabla 1. Mínimos y máximos de la temperatura superficial del mar $\left(\mathrm{SST},{ }^{\circ} \mathrm{C}\right)$, y el mes en el que se presentaron, para la zona cerca de la costa $(\mathrm{de}$ 0 a $50 \mathrm{~km}$ ) y la zona oceánica del transecto frente a La Jolla (TLJ) y del transecto frente a la bahía San Quintín (TSQB) en cada año.

\begin{tabular}{|c|c|c|c|c|c|c|c|c|c|c|c|c|c|c|c|}
\hline $\begin{array}{l}\text { TLJ } \\
\text { Inshore }\end{array}$ & 2002 & 2003 & 2004 & 2005 & 2006 & 2007 & 2008 & 2009 & 2010 & 2011 & 2012 & 2013 & 2014 & 2015 & 2016 \\
\hline Min. SST & 16.2 & 14.9 & 14.8 & 15.0 & 14.0 & 14.3 & 13.6 & 14.9 & 15.2 & 14.2 & 14.2 & 14.2 & 15.8 & 17.0 & 16.2 \\
\hline \multirow[t]{2}{*}{ Max. SST } & 19.6 & 21.7 & 21.8 & 21.2 & 21.7 & 21.8 & 21.4 & 21.6 & 19.2 & 19.6 & 21.9 & 21.3 & 22.7 & 24.0 & 22.5 \\
\hline & Jul & Sep & Sep & Aug & Jul & Aug & Aug & Sep & Oct & Sep & Sep & Sep & Sep & Oct & Aug \\
\hline \multirow[t]{2}{*}{ Min. SST } & 16.3 & 15.7 & 15.2 & 15.7 & 15.0 & 14.9 & 13.0 & 15.2 & 11.9 & 14.4 & 14.8 & 14.7 & 15.8 & 17.5 & 16.4 \\
\hline & Dec & Jun & Feb & Feb & Mar & Jan & Jun & May & Jun & Feb & Mar & Feb & Feb & Jan & Jan \\
\hline Max. SST & 19.8 & 21.6 & 21.8 & 21.1 & 21.8 & 21.1 & 20.9 & 21.6 & 19.2 & 20.3 & 22.0 & 21.2 & 22.9 & 23.6 & 21.7 \\
\hline \multirow[t]{2}{*}{ Min. SST } & 15.8 & 13.6 & 14.5 & 14.6 & 13.2 & 13.6 & 13.7 & 14.0 & 14.2 & 13.2 & 13.6 & 14.1 & 15.2 & 16.4 & 16.0 \\
\hline & Dec & May & Feb & Apr & Mar & Apr & Feb & Mar & Dec & Mar & Mar & Feb & Apr & May & Mar \\
\hline \multirow[t]{2}{*}{ Max. SST } & 19.5 & 21.7 & 21.8 & 20.8 & 22.0 & 21.4 & 20.7 & 21.7 & 18.8 & 20.2 & 22.2 & 21.1 & 22.8 & 25.1 & 22 \\
\hline & Sep & Sep & Sep & Aug & Sep & Aug & Oct & Sep & Sep & Sep & Sep & Aug & Sep & Jul & Sep \\
\hline \multicolumn{16}{|l|}{ TSQB } \\
\hline Min. SST & 16.8 & 13.4 & 15.2 & 16 & 14.4 & 15.2 & 14.6 & 14.7 & 12.0 & 5.9 & 15.1 & 14.8 & 16.3 & 17.9 & 16.9 \\
\hline
\end{tabular}

years. This gradient was not clear during the cold 2007-2012 period. During the second season, waters were relatively warm along the entire extension of both transects (Fig. 3). Thus, there was a clear SST seasonal signal throughout the transects.

On TLJ the SST gradient was inverted in summer, with higher inshore than offshore values, as mentioned above. But this inversion changed from year to year, often taking place between June and August, and in some years it began in May and ended until September. During this gradient reversal, SST differences between inshore warm waters and offshore waters with lower SST ranged from $\sim 0.7^{\circ} \mathrm{C}$ (in most cases) to $\sim 2.5{ }^{\circ} \mathrm{C}$.

In the inshore zone of both transects there were $\mathrm{Chl}_{\text {sat }}$ and PP variations with clear seasonal and interannual components periodo 2007-2012. Durante la segunda temporada, las aguas de toda la extensión de ambos transectos fueron relativamente cálidas (Fig. 3). Por tanto, hubo una clara señal estacional de TSM a través de los transectos.

El gradiente de TSM se invirtió en verano en TLJ, con valores más altos en la zona costera que en la zona oceánica, como ya se mencionó. Pero esta inversión cambió de año a año presentándose a menudo entre junio y agosto, mientras que en algunos años comenzó en mayo y terminó hasta el final de septiembre. Cuando se presentó la reversión del gradiente, las diferencias de TSM entre las aguas cálidas de la zona costera y las de menor TSM de la zona oceánica fueron entre $\sim 0.7{ }^{\circ} \mathrm{C}$ (la mayoría de los casos) y $\sim 2.5^{\circ} \mathrm{C}$.

La zona costera de ambos transectos presentó variaciones de $\mathrm{Chl}_{\text {sat }}$ y PP con componentes estacionales e interanuales 
(Tables 2, 3). In the month-to-month variation, $\mathrm{Ch}_{\mathrm{sat}}$ and $\mathrm{PP}$ values were relatively high $\left(\geq 1.0 \mathrm{mg} \cdot \mathrm{m}^{-3}\right.$ and $\geq 1.0 \mathrm{~g} \mathrm{C} \cdot \mathrm{m}^{-2} \cdot \mathrm{d}^{-1}$, respectively) in the TLJ inshore zone during spring and summer, although high values were occasionally observed further from shore $(70-160 \mathrm{~km})$. Values $>1.0 \mathrm{mg} \cdot \mathrm{m}^{-3}$ and $>1.0 \mathrm{~g} \mathrm{C} \cdot \mathrm{m}^{-2} \cdot \mathrm{d}^{-1}$ were frequently observed for autumn and winter. In the TSQB inshore zone, the month-to-month $\mathrm{Chl}_{\text {sat }}$ and PP variations often presented relatively high values $\left(\geq 1.0 \mathrm{mg} \cdot \mathrm{m}^{-3}\right.$ and $\geq 1.0 \mathrm{~g}$ $\mathrm{C} \cdot \mathrm{m}^{-2} \cdot \mathrm{d}^{-1}$, respectively) in winter, spring, and summer.

Inshore $\mathrm{Ch}_{\text {sat }}$ maxima were higher on TSQB (up to $38.6 \mathrm{mg} \cdot \mathrm{m}^{-3}$ ) than on TLJ (up to $12.0 \mathrm{mg} \cdot \mathrm{m}^{-3}$ ), and minima for both transects were similar. On TLJ, sometimes maximum $\mathrm{Ch}_{\mathrm{sat}}$ was not near the coast but between 30 and $150 \mathrm{~km}$. On TSQB, maximum $\mathrm{Chl}_{\text {sat }}$ was, on a few occasions, on the second pixel near the coast. In the TSQB inshore zone, $\mathrm{Chl}_{\text {sat }}$ showed exceptionally high values in 2005, 2011, and 2012. Offshore



Figure 3. Hovmöller diagrams for sea surface temperature (SST) along the transect off La Jolla (upper panel) and the transect off San Quintín Bay (lower panel).

Figura 3. Diagramas Hovmöller de la temperatura superficial del mar (SST) para el transecto frente a La Jolla (panel superior) y el transecto frente a la bahía San Quintín (panel inferior). claros (Tablas 2, 3). En la variación de mes a mes, los valores de $\mathrm{Chl}_{\text {sat }}$ y PP fueron relativamente altos $\left(\geq 1.0 \mathrm{mg} \cdot \mathrm{m}^{-3}\right.$ $\mathrm{y} \geq 1.0 \mathrm{~g} \mathrm{C} \cdot \mathrm{m}^{-2} \cdot \mathrm{d}^{-1}$, respectivamente) en la zona costera de TLJ en primavera y verano, aunque en ocasiones se detectaron valores altos de estas propiedades en mar adentro $(70-160 \mathrm{~km})$. Frecuentemente, también se detectaron valores $>1.0 \mathrm{mg} \cdot \mathrm{m}^{-3}$ y $>1.0 \mathrm{~g} \mathrm{C} \cdot \mathrm{m}^{-2} \cdot \mathrm{d}^{-1}$ en otoño e invierno. En la zona costera de TBSQ, las variaciones de mes a mes de $\mathrm{Chl}_{\text {sat }}$ y PP presentaron valores a menudo relativamente altos $\left(\geq 1.0 \mathrm{mg} \cdot \mathrm{m}^{-3} \mathrm{y} \geq 1.0 \mathrm{~g} \mathrm{C} \cdot \mathrm{m}^{-2} \cdot \mathrm{d}^{-1}\right.$, respectivamente $)$ en invierno, primavera y verano.

En la zona costera, los máximos de $\mathrm{Ch}_{\mathrm{sat}}$ fueron mayores en TBSQ (hasta $38.6 \mathrm{mg} \cdot \mathrm{m}^{-3}$ ) que en TLJ (hasta $12.0 \mathrm{mg} \cdot \mathrm{m}^{-3}$ ), y los mínimos fueron similares. En TLJ, algunas veces el máximo de $\mathrm{Chl}_{\text {sat }}$ no estuvo adyacente a la costa, sino entre 30 y $150 \mathrm{~km}$. En TBSQ, pocas veces el máximo de $\mathrm{Chl}_{\text {sat }}$ estuvo en el segundo pixel adyacente a la costa. En la zona costera de TBSQ, $\mathrm{Chl}_{\text {sat }}$ presentó valores excepcionalmente altos en 2005, 2011 y 2012. En la zona oceánica, los valores máximos de $\mathrm{Chl}_{\text {sat }}$ en TLJ fueron relativamente altos (hasta $\left.4.6 \mathrm{mg} \cdot \mathrm{m}^{-3}\right)$, mientras que los de TBSQ fueron, en general, bajos $\left(0.7 \mathrm{mg} \cdot \mathrm{m}^{-3}\right)$, aunque excepcionalmente llegaron a $6.1 \mathrm{mg} \cdot \mathrm{m}^{-3}$. Los valores de PP fueron paralelos a los de $\mathrm{Chl}_{\text {sat, }}$, aunque los de PP en la zona costera de TLJ fueron mayores (hasta $8.6 \mathrm{~g} \mathrm{C} \cdot \mathrm{m}^{-2} \cdot \mathrm{d}^{-1}$ ) que los de la zona costera de TBSQ

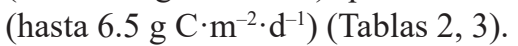

Los diagramas Hovmöller para $\mathrm{Ch}_{\text {sat }}$ de ambos transectos muestran una mayor variación espacial y temporal que aquellos para TSM (Figs. 3, 4). Las variaciones estacionales e interanuales fueron evidentes para $\mathrm{Chl}_{\text {sat }}$ y TSM, pero hubo mayor contraste para $\mathrm{Chl}_{\text {sat }}$ que para TSM. En la zona costera, $\mathrm{Chl}_{\text {sat }}$ presentó valores más elevados en TBSQ que en TLJ. En el caso del diagrama de $\mathrm{Chl}_{\text {sat }}$ para TLJ los valores fueron relativamente elevados en la zona oceánica, principalmente en 2005, 2006 y 2011. En 2005 hubieron valores de $>4 \mathrm{mg} \cdot \mathrm{m}^{-3}$ hasta $\sim 140 \mathrm{~km}$ de la costa, y en 2011 hubieron valores de $\sim 2 \mathrm{mg} \cdot \mathrm{m}^{-3}$ hasta $\sim 200 \mathrm{~km}$ de la costa (Fig. 4). También hubieron valores relativamente altos de $\mathrm{Chl}_{\text {sat }}\left(\sim 2 \mathrm{mg} \cdot \mathrm{m}^{-3}\right)$ en las aguas $>100 \mathrm{~km}$ de la costa en TBSQ en 2008, 2009 y 2013. En la zona costera de TLJ los valores de $\mathrm{Chl}_{\text {sat }}$ fueron muy bajos en 2004, 2014, 2015 y 2016, pero en la zona costera de TBSQ los valores de $\mathrm{Chl}_{\text {sat }}$ fueron muy bajos sólo en 2004 (Fig. 4).

Los resultados de las pruebas Mann-Whitney para comparar $\mathrm{Chl}_{\text {sat }}$ entre las 2 temporadas, las 2 zonas y los 2 transectos indican que en todos los casos hubo diferencias significativas, a excepción de los valores de $\mathrm{Chl}_{\text {sat }}$ para las zonas costeras de ambos transectos en la segunda temporada, que no fueron significativamente diferentes entre transectos (Tabla 4). Estas pruebas y la visualización de los datos indican que, en general, los valores de $\mathrm{Chl}_{\text {sat }}$ fueron significativamente mayores en la primera temporada que en la segunda para las 2 zonas de los 2 transectos; que los valores de $\mathrm{Chl}_{\text {sat }}$ fueron significativamente mayores en las zonas costeras que en las zonas oceánicas de ambos transectos en ambas temporadas; y que los valores de $\mathrm{Chl}_{\text {sat }}$ fueron significativamente mayores en la 
Table 2. Phytoplankton biomass obtained from satellite imagery $\left(\mathrm{Ch}_{\mathrm{sat}}, \mathrm{mg} \cdot \mathrm{m}^{-3}\right)$ and primary production $\left(\mathrm{PP}, \mathrm{g} \mathrm{C} \cdot \mathrm{m}^{-2} \cdot \mathrm{d}^{-1}\right) \mathrm{minima}$ and $\mathrm{maxima}$ for the inshore $(0$ to $50 \mathrm{~km})$ and furthest offshore $(\sim 250 \mathrm{~km})$ zones on the transect off La Jolla (TLJ) in each year.

Tabla 2. Mínimos y máximos de la biomasa fitoplanctónica obtenida de imágenes de satélite $\left(\mathrm{Chl}_{\mathrm{sat}}, \mathrm{mg} \cdot \mathrm{m}^{-3}\right) \mathrm{y}$ producción primaria $\left(\mathrm{PP}, \mathrm{g} \mathrm{C} \cdot \mathrm{m}^{-2} \cdot \mathrm{d}^{-1}\right)$ para la zona costera $(\mathrm{de} 0 \mathrm{a} 50 \mathrm{~km})$ y la zona más oceánica $(\sim 250 \mathrm{~km})$ del transecto frente a La Jolla (TLJ) en cada año.

\begin{tabular}{|c|c|c|c|c|c|c|c|c|c|c|c|c|c|c|c|}
\hline $\begin{array}{l}\text { TLJ } \\
\text { Inshore }\end{array}$ & 2002 & 2003 & 2004 & 2005 & 2006 & 2007 & 2008 & 2009 & 2010 & 2011 & 2012 & 2013 & 2014 & 2015 & 2016 \\
\hline \multirow[t]{2}{*}{ Min. $\mathrm{Chl}_{\text {sat }}$} & 0.2 & 0.2 & 0.1 & 0.1 & 0.1 & 0.1 & 0.1 & 0.1 & 0.2 & 0.2 & 0.1 & 0.1 & 0.1 & 0.1 & 0.1 \\
\hline & Jul & Feb & Aug & Mar & Jul & Aug & Aug & Aug & May & Aug & Aug & Aug & Oct & Aug & Mar \\
\hline \multirow[t]{2}{*}{ Min. PP } & 0.6 & 0.5 & 0.5 & 0.5 & 0.7 & 0.8 & 0.7 & 0.6 & 0.8 & 0.8 & 0.6 & 0.5 & 0.4 & 0.4 & 0.4 \\
\hline & Dec & Jan & Feb & Feb & Feb & Aug & Nov & Oct & Dec & Dec & Aug & Dec & Dec & Aug & Oct \\
\hline \multirow[t]{2}{*}{ Max. Chl $\mathrm{l}_{\text {sat }}$} & 1.4 & 12.0 & 2.9 & 7.5 & 5.1 & 4.4 & 9.7 & 3.6 & 3.2 & 6.5 & 9.6 & 3.1 & 2.5 & 2.3 & 1.5 \\
\hline & Aug & May & Jun & Aug & Mar & May & Apr & Jun & Aug & Mar & Mar & Apr & Apr & Jun & Jun \\
\hline \multirow[t]{2}{*}{ Max. PP } & 3.5 & 5.5 & 5.4 & 8.6 & 6.3 & 5.9 & 7.5 & 7.5 & 4.7 & 4.4 & 5.3 & 4.0 & 3.1 & 4.9 & 3.4 \\
\hline & Jul & May & Apr & Jun & Apr & Apr & Apr & Jun & Mar & Jun & Mar & Apr & May & Apr & May \\
\hline \multicolumn{16}{|l|}{ TLJ } \\
\hline \multirow[t]{2}{*}{ Min. $\mathrm{Chl}_{\text {sat }}$} & $<0.1$ & $<0.1$ & $<0.1$ & $<0.1$ & $<0.1$ & $<0.1$ & $<0.1$ & $<0.1$ & 0.1 & $<0.1$ & 0.1 & $<0.1$ & $<0.1$ & 0.1 & 0.1 \\
\hline & Sep & Oct & Jul & Jul & Jul & Aug & Aug & Jul & Nov & May & Sep & Jun & Sep & Oct & May \\
\hline \multirow[t]{2}{*}{ Min. PP } & 0.3 & 0.3 & 0.3 & 0.3 & 0.3 & 0.3 & 0.3 & 0.3 & 0.3 & 0.3 & 0.3 & 0.3 & 0.2 & 0.3 & 0.4 \\
\hline & Sep & $\mathrm{Feb}$ & Nov & Mar & Feb & Sep & Aug & Jul & Nov & Sep & Sep & Jun & Dec & Oct & Oct \\
\hline \multirow[t]{2}{*}{ Max. $\mathrm{Chl}_{\text {sat }}$} & 0.6 & 0.5 & 0.4 & 4.2 & 4.6 & 0.7 & 1.9 & 0.7 & 1.7 & 1.1 & 0.8 & 0.5 & 0.2 & 0.5 & 0.4 \\
\hline & Aug & Sep & Feb & Jul & May & Feb & Apr & Feb & Dec & Jan & May & Feb & Feb & May & Jun \\
\hline \multirow[t]{2}{*}{ Max. PP } & 1.2 & 2.8 & 0.8 & 2.9 & 2.1 & 1.4 & 1.6 & 1.3 & 1.4 & 1.6 & 1.5 & 1.4 & 0.9 & 1.0 & 0.9 \\
\hline & Aug & May & Jun & Jul & May & Apr & Apr & Jun & Jul & Apr & May & Jul & May & May & May \\
\hline
\end{tabular}

$\mathrm{Chl}_{\mathrm{sat}}$ maxima on TLJ were relatively high (up to $4.6 \mathrm{mg} \cdot \mathrm{m}^{-3}$ ), while those on TSQB were generally low $\left(0.7 \mathrm{mg} \cdot \mathrm{m}^{-3}\right)$ but exceptionally as high as $6.1 \mathrm{mg} \cdot \mathrm{m}^{-3}$. The PP plots and the $\mathrm{Chl}_{\text {sat }}$ plots behaved very similar, although PP values in inshore waters were greater on TLJ (up to $8.6 \mathrm{~g} \mathrm{C} \cdot \mathrm{m}^{-2} \cdot \mathrm{d}^{-1}$ ) than on TSQB (up to $6.5 \mathrm{~g} \mathrm{C} \cdot \mathrm{m}^{-2} \cdot \mathrm{d}^{-1}$ ) (Tables 2,3 ).

Hovmöller diagrams for $\mathrm{Chl}_{\text {sat }}$ on both transects showed greater spatial and temporal variations than those for SST (Figs. 3, 4). Seasonal and interannual variations were evident for $\mathrm{Chl}_{\text {sat }}$ and SST but with greater contrast for $\mathrm{Chl}_{\text {sat }}$ than for SST. Chl $\mathrm{Sat}_{\text {was }}$ higher in the TSQB inshore zone than those in the TLJ inshore zone. In the $\mathrm{Chl}_{\text {sat }}$ diagram for TLJ, values were relatively high offshore, mainly in 2005, 2006, and 2011. In 2005 values were $>4 \mathrm{mg} \cdot \mathrm{m}^{-3}$ in patches from the inshore zone to $\sim 140 \mathrm{~km}$ from the coast; in 2011 values were $\sim 2 \mathrm{mg} \cdot \mathrm{m}^{-3}$ in patches from the inshore zone to $\sim 200 \mathrm{~km}$ from the coast (Fig. 4). There were also relatively high $\mathrm{Chl}_{\text {sat }}$ values $\left(\sim 2 \mathrm{mg} \cdot \mathrm{m}^{-3}\right)$ in TSQB waters $>100 \mathrm{~km}$ offshore in 2008, 2009, and 2013. In the TLJ inshore zone $\mathrm{Chl}_{\text {sat }}$ values were very low in 2004, 2014, 2015, and 2016, but in the TSQB inshore zone $\mathrm{Chl}_{\text {sat }}$ values were low only in 2004 (Fig. 4). zona costera de TBSQ que en la zona costera de TLJ en la primera temporada. En la zona oceánica, los valores de $\mathrm{Chl}_{\mathrm{sat}}$ fueron significativamente mayores en TLJ que en TBSQ en ambas temporadas.

Las series de tiempo para los cuadrantes costeros frente a La Jolla (QLJ) y la bahía San Quintín (QBSQ) mostraron variaciones estacionales e interanuales claras, con la variancia mayor en el ciclo anual (Fig. 5). En ambos cuadrantes, los máximos de TSM $\left(23.9{ }^{\circ} \mathrm{C}\right)$ y las TSM mínimas anuales más altas $\left(\sim 17.5^{\circ} \mathrm{C}\right)$ se presentaron en 2015 . La diferencia estacional de TSM más grande para QLJ fue $\sim 7.8^{\circ} \mathrm{C}$ y para QBSQ fue $\sim 8.1^{\circ} \mathrm{C}$, ambas en 2006 . Las diferencias más grandes entre máximos de años consecutivos fueron $2.5^{\circ} \mathrm{C}$ para QLJ y $2.9^{\circ} \mathrm{C}$ para QBSQ, ambas entre 2009 y 2010. En la serie de tiempo de $\mathrm{Chl}_{\text {sat }}$ para QBSQ, donde cada número es un promedio para 4 pixeles, no se presentaron los valores excepcionalmente altos de 2005, 2011 y 2012 que se observaron para el transecto (Fig. 5, Tabla 2). En esta serie de tiempo, los valores más altos fueron de hasta $11.6 \mathrm{mg} \cdot \mathrm{m}^{-3} \mathrm{y}$ se presentaron en 2003, 2007 y 2008. Los valores más altos de $\mathrm{Chl}_{\text {sat }}$ para la serie de QLJ fueron de hasta $9.5 \mathrm{mg} \cdot \mathrm{m}^{-3} \mathrm{y}$ se presentaron en 2003, 2008 y 2012. Los valores más bajos de 
Table 3. Phytoplankton biomass obtained from satellite imagery $\left(\mathrm{Ch}_{\text {sat }}, \mathrm{mg} \cdot \mathrm{m}^{-3}\right)$ and primary production $\left(\mathrm{PP}, \mathrm{g} \mathrm{C} \cdot \mathrm{m}^{-2} \cdot \mathrm{d}^{-1}\right) \mathrm{minima}$ and maxima for the inshore $(0$ to $50 \mathrm{~km})$ and furthest offshore $(\sim 250 \mathrm{~km})$ zones on the transect off San Quintín Bay (TSQB) in each year.

Tabla 3. Mínimos y máximos de la biomasa fitoplanctónica obtenida de imágenes de satélite $\left(\mathrm{Chl}_{\text {sat }}, \mathrm{mg} \cdot \mathrm{m}^{-3}\right)$ y producción primaria $\left(\mathrm{PP}, \mathrm{g} \mathrm{C} \cdot \mathrm{m}^{-2} \cdot \mathrm{d}^{-1}\right)$ para la zona costera (de 0 a $50 \mathrm{~km}$ ) y la zona más oceánica $(\sim 250 \mathrm{~km})$ del transecto frente a la bahía San Quintín (TSQB) en cada año.

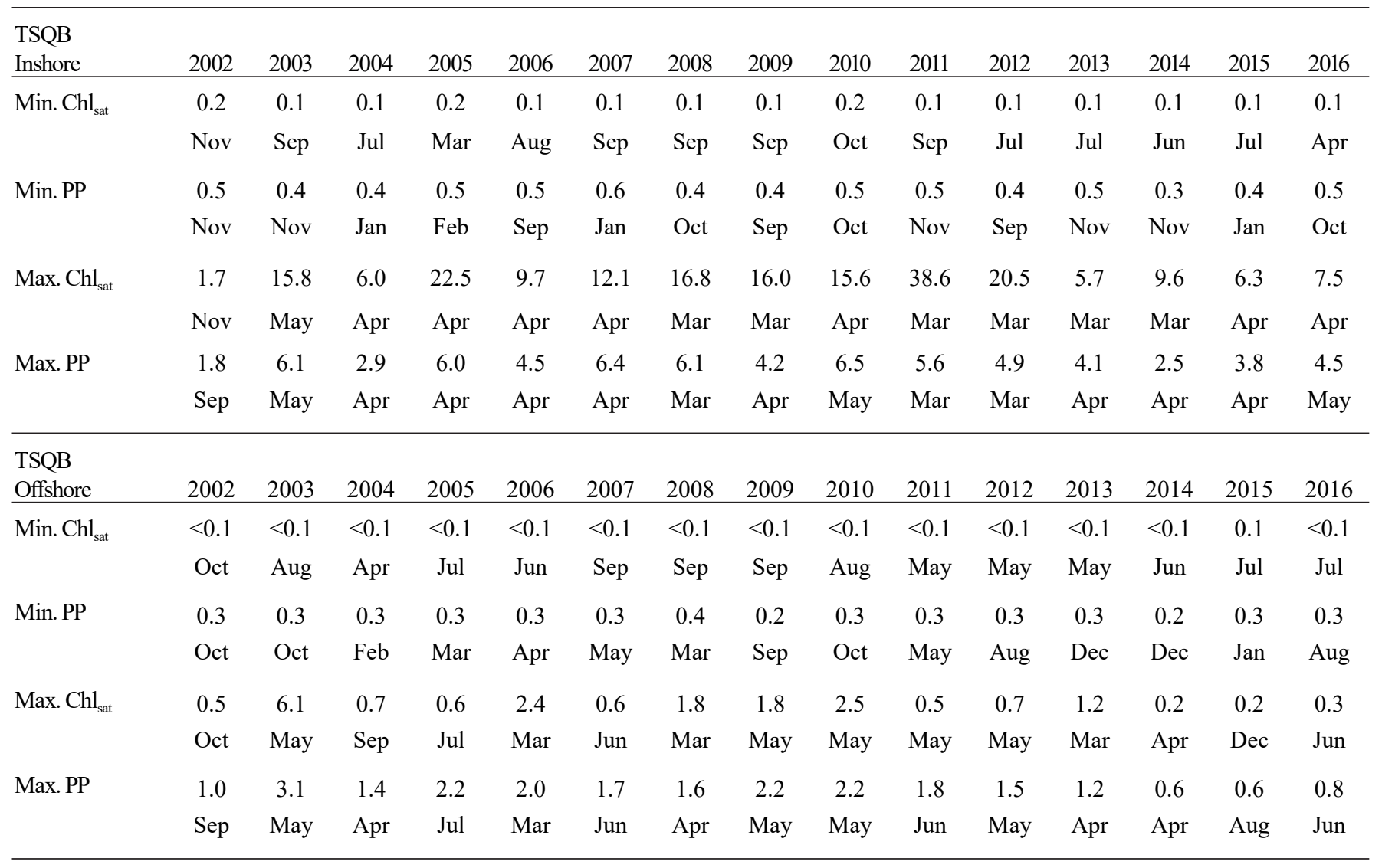

Results from the Mann-Whitney tests comparing $\mathrm{Chl}_{\text {sat }}$ between the 2 seasons, the 2 zones, and the 2 transects indicate significant differences in all cases, with the exception of $\mathrm{Chl}_{\text {sat }}$ values for the inshore zones of both transects in the second season, which were not significantly different between transects (Table 4). These tests and the visualization of the data indicate that, in general, $\mathrm{Chl}_{\text {sat }}$ values were significantly higher in the first season than in the second season in both zones of both transects; that $\mathrm{Chl}_{\text {sat }}$ values were significantly higher in the inshore zones than in the offshore zones of both transects in both seasons; and that $\mathrm{Ch}_{\text {sat }}$ values were significantly higher in the inshore zone of TSQB than in the inshore zone of TLJ in the first season. In the offshore zone, $\mathrm{Chl}_{\text {sat }}$ values were significantly higher on TLJ than on TSQB in both seasons.

The time series for the coastal quadrants off La Jolla (QLJ) and off San Quintín Bay (QSQB) showed clear seasonal and interannual variations, with higher variance in the annual cycle (Fig. 5). In both quadrants, maxima SST $\left(23.9^{\circ} \mathrm{C}\right)$ and the highest yearly SST minima $\left(\sim 17.5^{\circ} \mathrm{C}\right)$ occurred in 2015. The largest seasonal SST difference for QLJ was $\sim 7.8^{\circ} \mathrm{C}$ and that for QSQB was $\sim 8.1{ }^{\circ} \mathrm{C}$, both occurring in
$\mathrm{Chl}_{\text {sat }}$ para QLJ se presentaron en 2014, 2015 y 2016, y los más bajos para QBSQ en 2004 y 2015. La diferencia estacional más grande de $\mathrm{Chl}_{\text {sat }}$ para QLJ fue $\sim 7.9 \mathrm{mg} \cdot \mathrm{m}^{-3}$, en 2008, y la de QBSQ fue $\sim 11.2 \mathrm{mg} \cdot \mathrm{m}^{-3}$, en 2003 . La diferencia más grande entre máximos de $\mathrm{Chl}_{\text {sat }}$ de años consecutivos fue $6.1 \mathrm{mg} \cdot \mathrm{m}^{-3}$, entre 2008 y 2009 , para QLJ, y $10.6 \mathrm{mg} \cdot \mathrm{m}^{-3}$, entre 2003 y 2004, para QBSQ. En las series de tiempo para QLJ y QBSQ, los valores de PP fueron paralelos a los de $\mathrm{Chl}_{\text {sat }}$ pero no presentaron mínimos extremos (Fig. 5).

El análisis espectral de las series de tiempo confirma que la mayor parte de la variancia se presentó en el periodo anual (no ilustrado). Las variancias espectrales de las series de tiempo de TSM fueron muy similares para ambos cuadrantes. Sin embargo, en el caso de $\mathrm{Chl}_{\text {sat }}$ y PP, las variancias espectrales de las series de QBSQ fueron mayores que las de las series de QLJ. La variancia espectral de TSM para ambos cuadrantes mostró muy poca variación intra-anual, mientras que los espectros de $\mathrm{Ch}_{\mathrm{sat}}$ y PP mostraron picos de variancia espectral en diferentes frecuencias intra-anuales (semi-anual y otras). El análisis espectral no mostró con claridad los componentes interanuales de variancia, posiblemente porque nuestras series de tiempo son muy cortas (no ilustrado). 
2006. The largest differences between maxima of consecutive years were $2.5^{\circ} \mathrm{C}$ for QLJ and $2.9^{\circ} \mathrm{C}$ for QSQB, both between 2009 and 2010. The $\mathrm{Chl}_{\text {sat }}$ time series for QSQB, where each number is an average for 4 pixels, showed no exceptionally high values for 2005, 2011, and 2012 such as those observed for the transect (Fig. 5, Table 2). In this time series the highest values were up to $11.6 \mathrm{mg} \cdot \mathrm{m}^{-3}$ and occurred in 2003, 2007, and 2008. The highest $\mathrm{Chl}_{\text {sat }}$ values for QLJ were recorded in 2003, 2008, and 2012, and they were up to $9.5 \mathrm{mg} \cdot \mathrm{m}^{-3}$. The lowest $\mathrm{Chl}_{\text {sat }}$ values for QLJ were recorded in 2014, 2015, and 2016, and the lowest for QSQB were recorded in 2004 and 2015. The largest seasonal $\mathrm{Chl}_{\text {sat }}$ difference for QLJ was $\sim 7.9 \mathrm{mg} \cdot \mathrm{m}^{-3}$, in 2008 , and that for QSQB was $\sim 11.2 \mathrm{mg} \cdot \mathrm{m}^{-3}$, in 2003 . The largest difference between $\mathrm{Chl}_{\text {sat }}$ maxima for consecutive years was 6.1 $\mathrm{mg} \cdot \mathrm{m}^{-3}$, between 2008 and 2009 , for QLJ and $10.6 \mathrm{mg} \cdot \mathrm{m}^{-3}$, between 2003 and 2004, for QSQB. In the time series for QLJ and QSQB, PP values were parallel to those of $\mathrm{Chl}_{\text {sat }}$ but showed no extreme minima (Fig. 5).

The time series spectral analysis confirms that most of the variance occurred in the annual period (not illustrated). Spectral variances for the SST time series were very similar for both quadrants. In the case of $\mathrm{Chl}_{\text {sat }}$ and PP, however, spectral variances for the QSQB time series were greater than those for the QLJ time series. The SST time series spectral variance for both quadrants showed very small intra-annual variation, while those for $\mathrm{Ch}_{\text {sat }}$ and PP showed peaks of spectral variance at different intra-annual frequencies (semiannual and other frequencies). Spectral analysis did not clearly show the interannual components of variance, possibly because our time series were very short (not illustrated).

\section{Discussion}

In the inshore zone of both transects, the seasonal cycle of SST, $\mathrm{Chl}_{\text {sat }}$, and PP is related to the dynamics of the CCS. The California Current flux and coastal upwelling intensify in spring and the beginning of summer, promoting a strong seasonal biological signal, as described by Espinosa-Carreón et al. (2004). Lynn et al. (1982) indicated that a late spring-early summer phytoplankton bloom in the California Current occurs because that is when the stability maximum shoals and intensifies inshore. At the end of autumn and beginning of winter the California Current flux and coastal upwelling are weak, and there is a surface countercurrent near the coast (Lynn and Simpson 1987, Durazo et al. 2010). This winter coastal surface countercurrent clearly produces higher SST and lower $\mathrm{Chl}_{\text {sat }}$ and PP values than the values observed for spring and summer (Figs. 2-4). As Arroyo-Loranca et al. (2015) indicated, the Coriolis Effect causes the surface countercurrent to inhibit coastal upwelling because it tends to accumulate water near the coast. However, our data show that in the weak upwelling period (second season) the $\mathrm{Chl}_{\text {sat }}$ values from the inshore zones of both transects often reached

\section{Discusión}

En la zona costera de ambos transectos, los ciclos estacionales de TSM, $\mathrm{Chl}_{\text {sat }}$ y PP están relacionados con la dinámica del SCC. El flujo de la corriente de California y las surgencias costeras se intensifican en primavera y a principios de verano, promoviendo una señal biológica estacional fuerte, como la descrita por Espinosa-Carreón et al. (2004). Lynn et al. (1982) indicaron que entre la primavera tardía y el verano temprano hay un florecimiento de fitoplancton en la corriente de California debido a que el máximo de estabilidad se hace somero y se intensifica cerca de la costa. Al final del otoño e inicio del invierno el flujo de la corriente de California y las surgencias costeras son débiles, y cerca de la costa hay una contracorriente superficial (Lynn y Simpson 1987, Durazo et al. 2010). Esta contracorriente

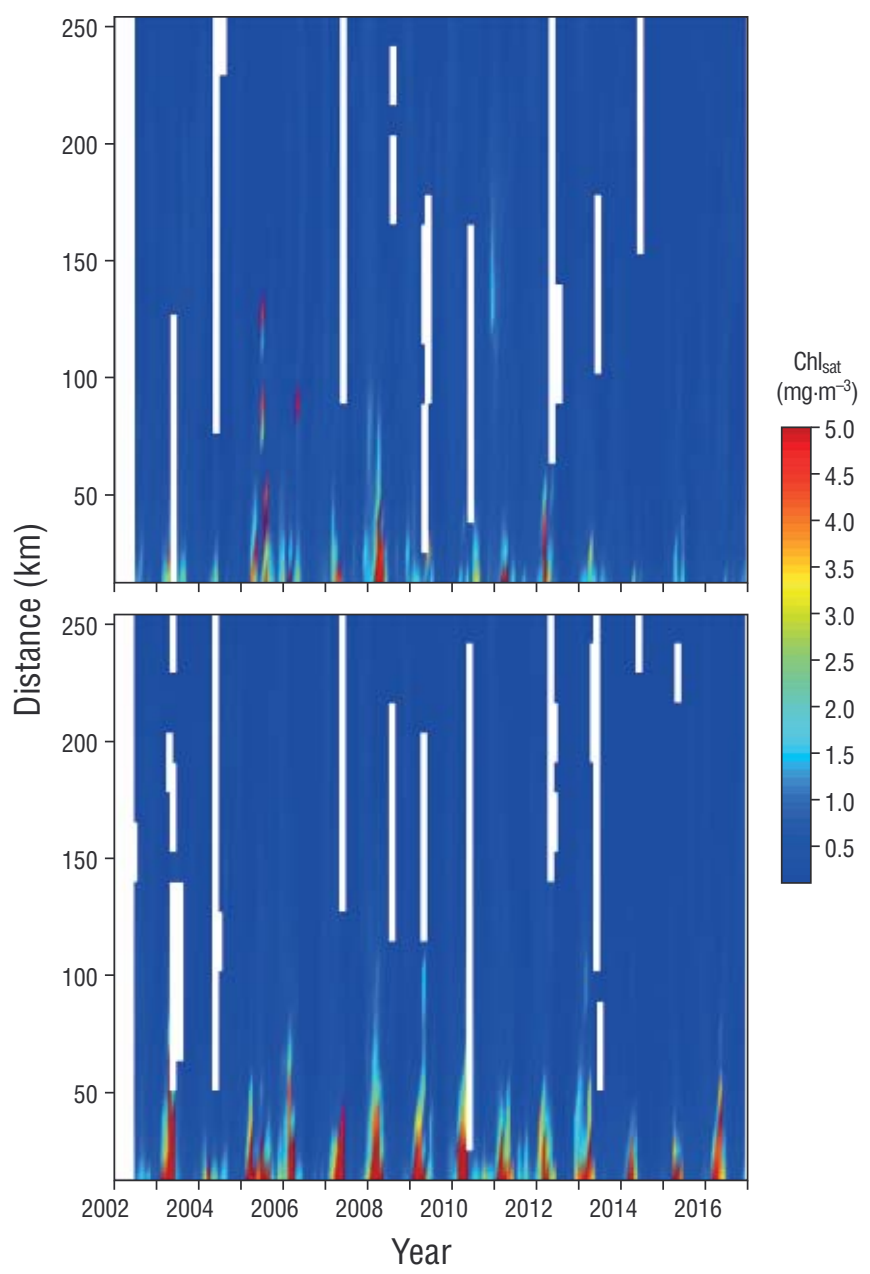

Figure 4. Hovmöller diagrams for Phytoplankton biomass $\left(\mathrm{Chl}_{\text {sat }}\right)$ along the transect off La Jolla (upper panel) and the transect off San Quintín Bay (lower panel).

Figura 4. Diagramas Hovmöller de la biomasa fitoplanctónica $\left(\mathrm{Chl}_{\text {sat }}\right)$ para el transecto frente a La Jolla (panel superior) y el transecto frente a bahía San Quintín (panel inferior). 
Table 4. Results of Mann-Whitney tests comparing phytoplankton biomass $\left(\mathrm{Chl}_{\text {sat }}\right)$ pairs of data sets as indicated (transect off La Jolla [TLJ], transect off San Quintín Bay [TSQB], coastal zone [IN], offshore zone $[\mathrm{OFF}])$. Significant differences are marked in bold.

Tabla 4. Resultados de las pruebas Mann-Whitney donde se comparan conjuntos de datos pareados de la biomasa fitoplanctónica $\left(\mathrm{Ch}_{\text {sat }}\right)$ según se indica (transecto frente a La Jolla [TLJ], transecto frente a bahía San Quintín [TSQB], zona costera [IN], zona oceánica $[\mathrm{OFF}])$. Las diferencias significativas se marcaron en negritas.

\begin{tabular}{llll}
\hline TLJ & First season IN vs second IN & $n=570$ & $\boldsymbol{P}<\mathbf{0 . 0 0 1}$ \\
& First season OFF vs second OFF & $n=2,220$ & $\boldsymbol{P}<\mathbf{0 . 0 4 5}$ \\
TSQB & First season IN vs second IN & $n=574$ & $\boldsymbol{P}<\mathbf{0 . 0 0 1}$ \\
& First season OFF vs second OFF & $n=2,213$ & $\boldsymbol{P}<\mathbf{0 . 0 0 1}$ \\
TLJ & First season IN vs OFF & $n=1,118$ & $\boldsymbol{P}<\mathbf{0 . 0 0 1}$ \\
& Second season IN vs OFF & $n=1,672$ & $\boldsymbol{P}<\mathbf{0 . 0 0 1}$ \\
TSQB & First season IN vs OFF & $n=1,118$ & $\boldsymbol{P}<\mathbf{0 . 0 0 1}$ \\
& Second season IN vs OFF & $n=1,665$ & $\boldsymbol{P}<\mathbf{0 . 0 0 1}$ \\
IN & First season TLJ vs TSQB & $n=472$ & $\boldsymbol{P}<\mathbf{0 . 0 0 1}$ \\
& Second season TLJ vs TSQB & $n=672$ & $P<0.822$ \\
OFF & First season TLJ vs TSQB & $n=1,764$ & $\boldsymbol{P}<\mathbf{0 . 0 0 1}$ \\
& Second season TLJ vs TSQB & $n=2,665$ & $\boldsymbol{P}<\mathbf{0 . 0 0 1}$ \\
\hline
\end{tabular}

$>1 \mathrm{mg} \cdot \mathrm{m}^{-3}$ (Figs. 2, 4), which indicates mesotrophic conditions. Thus, as Fargion (1989) indicated, the seasonal variation does not produce an extreme inshore oligotrophic situation during winter. As a comparison, Santamaría-del-Ángel et al. (1999) used data from the Coastal Zone Color Scanner for the Gulf of California to conclude that during the season with no upwelling, $\mathrm{Chl}_{\text {sat }}$ collapses to $<<0.1 \mathrm{mg} \cdot \mathrm{m}^{-3}$. In the furthest offshore area there was no clear biological seasonal signal for either transect (Fig. 4), as was reported by Fargion et al. (1993).

Kahru and Mitchell (2000) proposed dividing the CCS surface waters into an inshore eutrophic zone, an intermediate mesotrophic zone, and an offshore oligotrophic zone, under the criteria that eutrophic means $\mathrm{Chl}_{\mathrm{sat}}$ is $>1.0 \mathrm{mg} \cdot \mathrm{m}^{-3}$ and mesotrophic means $\mathrm{Chl}_{\text {sat }}$ is between 0.25 and $1.0 \mathrm{mg} \cdot \mathrm{m}^{-3}$. Based on $\mathrm{Ch}_{\text {sat }}$ data from the inshore zones of both transects, we divided the year into 2 seasons considering the values $>2.0 \mathrm{mg} \cdot \mathrm{m}^{-3}$ as indicative of eutrophic conditions, and values $<2.0 \mathrm{mg} \cdot \mathrm{m}^{-3}$ as indicative of mesotrophic conditions. We considered this criteria to be more appropriate because the inshore zones of both transects showed relatively high $\mathrm{Chl}_{\text {sat }}$ values even during the weak upwelling season.

The northward coastal flux in the SCB cyclonic eddy caused upwelling events in spring and the beginning of summer to be less intense on TLJ than on TSQB. Also, the offshore component of circulation off San Quintín Bay may intensify upwelling events on TSQB, as suggested by superficial costera claramente produce valores más altos de TSM y valores más bajos de $\mathrm{Chl}_{\text {sat }} \mathrm{y}$ PP en invierno que en primavera y verano (Figs. 2-4). Como lo mencionaron Arroyo-Loranca et al. (2015), el efecto de Coriolis causa el que la contracorriente superficial inhiba las surgencias costeras, porque tiende a acumular el agua cerca de la costa. Sin embargo, nuestros datos muestran que, en el periodo de debilitamiento de las surgencias (segunda temporada), los valores de $\mathrm{Ch}_{\text {sat }}$ de las zonas costeras de ambos transectos alcanzaron a menudo $>1 \mathrm{mg} \cdot \mathrm{m}^{-3}$ (Figs. 2, 4), lo cual indica una situación mesotrófica. Por tanto, como lo indicó Fargion (1989), la variación estacional no produce una situación oligotrófica extrema en la zona costera en invierno. Como comparación, Santamaría-del-Ángel et al. (1999) usaron datos del sensor Coastal Zone Color Scanner para el golfo de California y concluyeron que durante la temporada sin surgencias, la Chl se colapsa hasta valores $<<0.1 \mathrm{mg} \cdot \mathrm{m}^{-3}$. En la zona más alejada de la costa no se aprecia una variación biológica estacional clara en ambos transectos (Fig. 4), como lo reportaron Fargion et al. (1993).

Kahru y Mitchell (2000) propusieron dividir las aguas superficiales del SCC en una zona eutrófica costera, una mesotrófica intermedia y una oligotrófica oceánica, bajo el criterio de que eutrófico significa que $\mathrm{Chl}_{\text {sat }}$ es $>1.0 \mathrm{mg} \cdot \mathrm{m}^{-3}$ y mesotrófica es de 0.25 a $1.0 \mathrm{mg} \cdot \mathrm{m}^{-3}$. Con base en nuestros datos de $\mathrm{Chl}_{\text {sat }}$ de las zonas costeras de ambos transectos, dividimos los años en 2 temporadas considerando los valores $>2.0 \mathrm{mg} \cdot \mathrm{m}^{-3}$ como indicativos de condiciones eutróficas, y los valores $<2.0 \mathrm{mg} \cdot \mathrm{m}^{-3}$ como indicativos de condiciones mesotróficas. Consideramos que este criterio es más apropiado porque las zonas costeras de ambos transectos presentaron valores relativamente altos de $\mathrm{Chl}_{\text {sat }}$ aún en la segunda temporada con surgencias débiles.

El flujo costero hacia el norte en el giro ciclónico de la ensenada del Sur de California causa que las surgencias de primavera e inicio de verano sean menos fuertes en TLJ que en TBSQ. Aunado a esto, la componente de circulación hacia mar adentro frente a la bahía San Quintín podría intensificar los eventos de surgencia en TBSQ, como fue sugerido por Álvarez-Borrego (2004) (vea también la lengüeta con valores relativamente altos de $\mathrm{Chl}_{\text {sat }}$ moviéndose hacia mar adentro desde la zona costera frente a la bahía San Quintín en la Fig. 6). Esta diferencia en las intensidades de las surgencias en ambos transectos pudiese ser la causa de los valores menores de $\mathrm{Chl}_{\text {sat }}$ en la zona costera de TLJ comparados con aquellos en TBSQ (Figs. 2, 4; Tabla 2). Esto también explica los componentes estacionales de variancia de $\mathrm{Ch}_{\text {sat }}$ y PP más bajos para TLJ que para TBSQ en el análisis espectral (no ilustrado). De acuerdo con Eppley et al. (1979), la concentración superficial de nitrato es muy baja en las aguas costeras del sur de California, excepto durante periodos cortos de surgencia fuerte. Sin embargo, los valores de PP en TLJ fueron a menudo mayores que aquellos en TBSQ (Tabla 3). Esto se debe a que frente al sur de California la concentración de nitrato aumenta con la profundidad dentro de la zona 
Álvarez-Borrego (2004) (see also the plume with relatively high $\mathrm{Ch}_{\text {sat }}$ values going offshore from the coastal zone off San Quintín Bay in Fig. 6). These upwelling events lead to higher $\mathrm{Chl}_{\text {sat }}$ values on TSQB compared with those on TLJ (Figs. 2, 4; Table 2). This also explains the lower seasonal component of variance for $\mathrm{Chl}_{\text {sat }}$ and PP on TLJ than on TSQB in the spectral analysis (not illustrated). According to Eppley et al. (1979), surface nitrate concentration is very low in southern California coastal waters, except during short periods of strong upwelling. However, PP values on TLJ were often higher than those on TSQB (Table 3) because nitrate concentration off southern California increases with depth in the euphotic zone (Eppley et al. 1979) and because $\mathrm{Chl}_{\text {sat }}$ was lower and the euphotic zone was deeper on TLJ than on TSQB; a deeper euphotic zone increases PP, as shown by Lara-Lara et al. (1984) with in situ Chl and PP data from ${ }^{14} \mathrm{C}$ incubations in the Gulf of California. The relatively high $\mathrm{Chl}_{\text {sat }}$ values in the TLJ offshore zone, up to $\sim 200 \mathrm{~km}$ from the coast in years like 2005, 2006, and 2011(Fig. 4), were caused by upwelling jets coming from Point Conception and by Ekman pumping, as described by Münchow (2000) (see Fig. 6).

Interannual variations in $\mathrm{SST}, \mathrm{Chl}_{\mathrm{sat}}$, and $\mathrm{PP}$ in the inshore zone of both transects were somewhat irregular (Fig. 4). This and the presence of several SST, $\mathrm{Chl}_{\text {sat }}$, and PP minima and maxima along the transects during certain months (not illustrated), with no clear temporal pattern of variation, might indicate the influence of mesoscale phenomena. Strub et al. (1991) and Soto-Mardones et al. (2004) reported the presence of cyclonic and anticyclonic eddies off Baja California. Durazo et al. (2005) reported eddies and meanders in the CCS region off the northern and central parts of the peninsula. These mesoscale phenomena affect biological production in the study area, mainly along TLJ (Fig. 4) (Henson and Thomas 2007a, b).

The inshore SST, $\mathrm{Chl}_{\text {sat }}$, and PP interannual variations may have been caused mainly by the sequence of ENSO events and the Blob. Arroyo-Loranca et al. (2015) used $\mathrm{Chl}_{\text {sat }}$ Sea-viewing Wide-Field-of-view Sensor (SeaWIFS) and Aqua-MODIS data for a transect off Punta Eugenia (TPE) $\left(27^{\circ} 38^{\prime} \mathrm{N}\right)$, Baja California Sur, and concluded that, with the exception of the 1997-1998 El Niño, which was of the eastern Pacific (EP) type, $\mathrm{Ch}_{\text {sat }}$ data did not show any significant effect of El Niño events on their study area in the 1997-2012 period. However, the twenty-first century El Niño events have had significant effects on the biology of our study area. The 1982-1983 and the 1997-1998 El Niño events were of the EP type; in the twenty-first century, it was not until 2015-2016 that there was another EP type of El Niño. The 2002-2003, 2004-2005, and 2009-2010 El Niño events were of the central Pacific (CP) type. The CP type events have occurred more often in the twenty-first century (Lee and McPhaden 2010). The 2014 Blob and the 2015-2016 El Niño had a very strong effect on the TLJ inshore zone, with low $\mathrm{Ch}_{\text {sat }}$ values in the first season during 3 consecutive years; however, the impacts of these 2 events were not as strong on TSQB, since very low $\mathrm{Chl}_{\text {sat }}$ eufótica (Eppley et al. 1979), y también a que la profundidad de la zona eufótica fue mayor en TLJ que en TBSQ cuando los valores de $\mathrm{Chl}_{\text {sat }}$ fueron menores; esto aumenta PP porque se integra con mayor profundidad, como lo mostraron Lara-Lara et al. (1984) con datos in situ de Chl y de PP, con incubaciones con ${ }^{14} \mathrm{C}$ en el golfo de California. Los valores relativamente altos de $\mathrm{Chl}_{\text {sat }}$ en partes alejadas de la costa en TLJ, hasta $\sim 200 \mathrm{~km}$ de la costa en algunos años (e.g., 2005, 2006 y 2011; Fig. 4), se deben a chorros de agua de surgencia costera que provienen de punta Concepción y al bombeo de Ekman descrito por Münchow (2000) (ver Fig. 6).
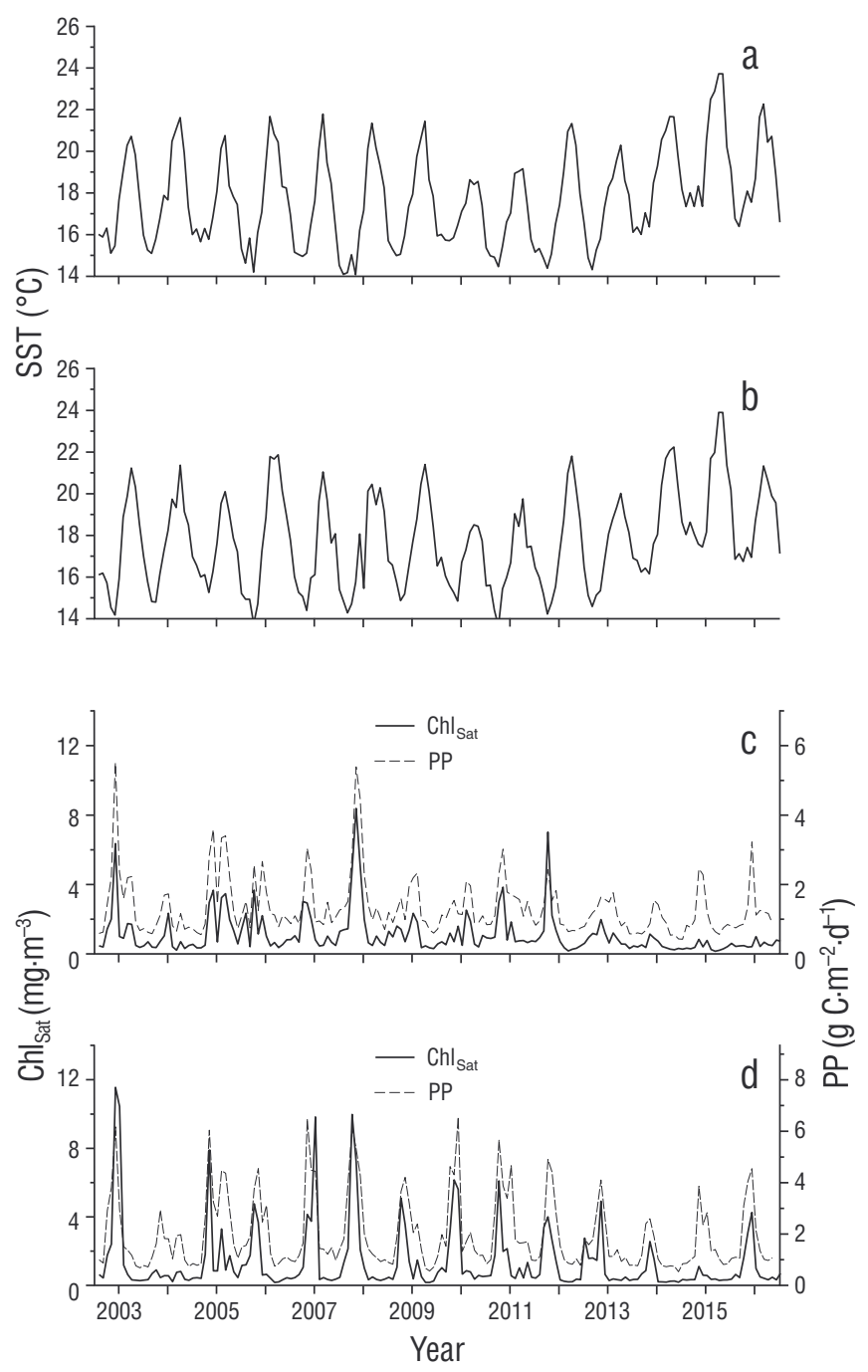

Figure 5. Time series of sea surface temperature (SST) off La Jolla (a), SST off San Quintín Bay (b), phytoplankton biomass ( $\left.\mathrm{Ch}_{\mathrm{sat}}\right)$ and primary production (PP) off La Jolla (c), and $\mathrm{Chl}_{\text {sat }}$ and PP off San Quintín Bay (d) in the $18 \times 18 \mathrm{~km}^{2}$ coastal quadrants.

Figura 5. Series de tiempo de temperatura superficial del mar (SST) frente a La Jolla (a), SST frente a bahía San Quintín (b), biomasa fitoplanctónica $\left(\mathrm{Ch}_{\text {sat }}\right)$ y producción primaria (PP) frente

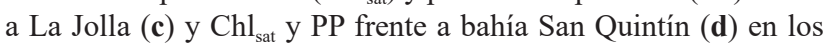
cuadrantes costeros de $18 \times 18 \mathrm{~km}^{2}$. 
values were found only in 2015 (Figs. 4, 5). On the other hand, the $2004 \mathrm{CP}$ type of El Niño had the same strong impact on both transects, TSQB and TLJ (Fig. 5), with the effect on $\mathrm{Chl}_{\text {sat }}$ as severe as that from the 2015 overlap of the Blob and the EP type of El Niño. The impact of ENSO events and other "anomalous warmings" is different along the different coastal areas of the CCS because of coastal dynamics, such as circulation, jets, eddies and meanders, and physiography (capes, islands). Using underwater gliders, Zaba and Rudnick (2016) found that off southern California, the thermocline was depressed and stratification was high from the summer of 2014 to the winter of 2015-2016. This may explain the very low $\mathrm{Chl}_{\text {sat }}$ values off La Jolla during 2014-2016. In addition, ENSO and other warming events may change significantly from location to location along the different coastal areas of the CCS, causing different biological effects, and this geographic variation raises an opportunity for future research. Our time series are too short for the spectral analysis to show clear interannual components of variance, but variations were present at periods larger than 2 years (not illustrated).

Since there was a time overlap of El Niño and the Blob, it is not clear if both events or only the Blob caused the decrease in $\mathrm{Chl}_{\text {sat }}$ and PP in the inshore waters of TLJ and TSQB throughout most of 2015. After September 2015 the effect of El Niño was the main cause for the low $\mathrm{Chl}_{\text {sat }}$ values in

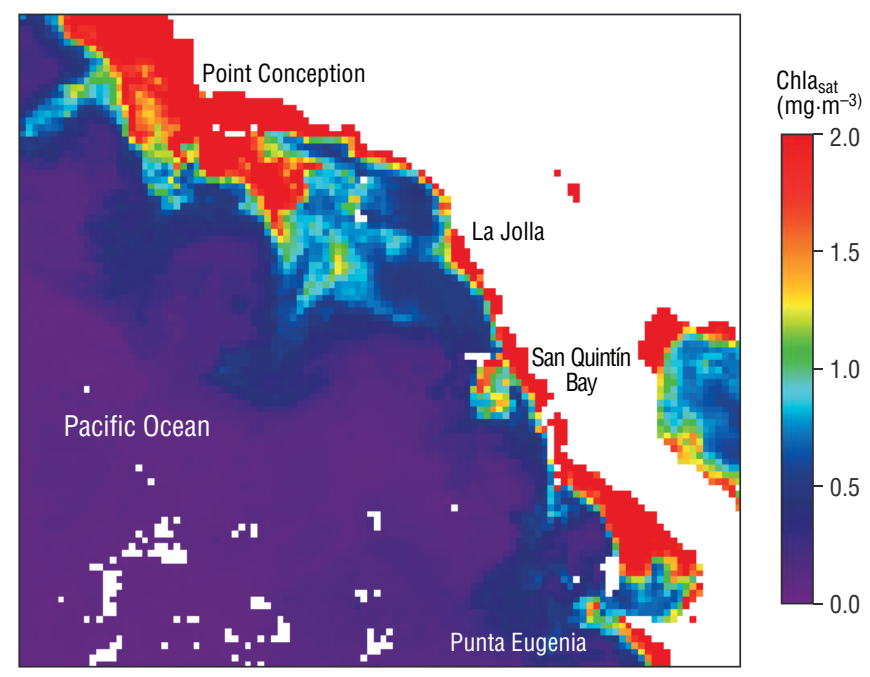

Figure 6. Example of an image showing plumes of relatively high phytoplankton biomass $\left(\mathrm{Chl}_{\mathrm{sat}}\right)$ flowing from Point Conception into the Southern California Bight (June 2005). Note the small plume flowing offshore from San Quintín Bay. The white areas are either land or areas lacking $\mathrm{Chl}_{\text {sat }}$ data because of persistent clouds.

Figura 6. Ejemplo de una imagen donde se muestran lengüetas de biomasa fitoplanctónica $\left(\mathrm{Chl}_{\mathrm{sat}}\right)$ relativamente elevada fluyendo de punta Concepción al interior de la ensenada del Sur de California (Junio 2005). También se aprecia una lengüeta pequeña que fluye hacia mar adentro desde la bahía San Quintín. Las áreas en blanco son tierra o áreas donde no hay datos de $\mathrm{Ch}_{\text {sat }}$ debido a nubes persistentes.
Las variaciones interanuales de TSM, $\mathrm{Chl}_{\text {sat }}$ y PP en la zona costera de ambos transectos fueron un tanto irregulares (Fig. 4). Esto y la presencia de varios mínimos y máximos de TSM, Chl sat y PP en los transectos durante ciertos meses (no ilustrado), sin un patrón de variación temporal claro, pueden indicar la influencia de fenómenos de mesoescala. Strub et al. (1991) y Soto-Mardones et al. (2004) reportaron la presencia de remolinos ciclónicos y anticiclónicos frente a Baja California. Durazo et al. (2005) reportaron remolinos y meandros para la región del SCC frente al norte y centro de la península. Estos fenómenos de mesoescala afectan la producción biológica del área de estudio, principalmente en TLJ (Fig. 4) (Henson y Thomas 2007a, b).

Las variaciones interanuales costeras de $\mathrm{TSM}, \mathrm{Ch}_{\text {sat }}$ y PP pudieron haber sido causadas principalmente por la secuencia de eventos ENOS y el Blob. Arroyo-Loranca et al. (2015) usaron datos de $\mathrm{Chl}_{\mathrm{sat}}$ de los sensores Sea-viewing Wide-Field-of-view Sensor (SeaWIFS) y Aqua-MODIS para un transecto frente a Punta Eugenia (TPE) $\left(27^{\circ} 38^{\prime} \mathrm{N}\right)$, Baja California Sur, y concluyeron que a excepción de El Niño 1997-1998, que fue del tipo Pacífico oriental (EP, por sus siglas en inglés), los datos de $\mathrm{Chl}_{\text {sat }}$ no mostraron ningún efecto significativo de eventos El Niño en su área de estudio, en el periodo 1997-2012. Sin embargo, han habido efectos significativos de los eventos El Niño del siglo XXI en la biología de nuestra área de estudio. Los eventos de El Niño de 1982-1983 y 1997-1998 fueron del tipo EP; en el siglo XXI, no fue sino hasta 2015-2016 que hubo otro El Niño del tipo EP. Los eventos de El Niño de 2002-2003, 2004-2005 y 2009-2010 fueron del tipo Pacifico central (CP, por sus siglas en inglés). Los eventos del tipo $\mathrm{CP}$ han ocurrido más a menudo en el siglo XXI (Lee y McPhaden 2010). El Blob de 2014 y El Niño de 2015-2016 tuvieron efectos muy fuertes en la zona costera de TLJ, donde se presentaron valores bajos de $\mathrm{Chl}_{\text {sat }}$ en la primera temporada, durante 3 años consecutivos; sin embargo, estos 2 eventos no tuvieron un impacto tan fuerte en TBSQ, ya que sólo en 2015 se presentaron valores muy bajos de $\mathrm{Chl}_{\text {sat }}$ (Figs. 4, 5). Por otra parte, El Niño del tipo CP de 2004 tuvo el mismo impacto fuerte en ambos transectos, TBSQ y TLJ (Fig. 5), con un efecto en la $\mathrm{Chl}_{\text {sat }}$ tan severo como el que ocurrió en 2015 con el traslape del Blob y El Niño del tipo EP. La dinámica costera, como la circulación, chorros, remolinos y meandros, y la fisiografía (cabos, islas) hacen que el impacto de eventos El Niño y de otros "calentamientos anómalos" difieran en áreas distintas del SCC. Zaba y Rudnick (2016) utilizaron deslizadores submarinos y encontraron que, frente al sur de California, la termoclina se hundió y la estratificación fue fuerte desde el verano de 2014 hasta el invierno de 2015-2016. Esto puede explicar los valores muy bajos de $\mathrm{Chl}_{\text {sat }}$ frente a La Jolla en 20142016. Además, los fenómenos como ENOS y otros eventos de calentamiento podrían variar significativamente de localidad a localidad en las áreas costeras del SCC, causando efectos diferentes, y el estudio de esta variación geográfica constituye un área de oportunidad para trabajos futuros. Nuestras series 
our study area. According to Robinson (2016), recent warming off Baja California occurred during 2 distinct periods: the first period occurred from May 2014 to April 2015, when SST increased because of weak coastal winds not associated with El Niño, the longest sustained record of negative wind anomalies occurred, and reduced wind stress suggested weak coastal upwelling; and the second period occurred from September to December 2015, when there were strong El Niño conditions (and clearly also during 2016 on TLJ).

The 2009-2010 El Niño was one of the strongest of the CP type in the last decades (Lee and McPhaden 2010). However, in our study areas, mainly TSQB, the impact of the 2004 event was stronger than that of the 2009-2010 event. The impact of the 2014 Blob was stronger than the impact of the El Niño events in the TLJ inshore zone, and the $2004 \mathrm{El}$ Niño had greatest impact on the TSQB inshore zone (Figs. 4, 5). Nevertheless, in our study area the effects of these warm events were not extremely strong; in spite of the significant decrease of $\mathrm{Chl}_{\text {sat }}$ and $\mathrm{PP}, \mathrm{Chl}_{\text {sat }}$ values were often $>1 \mathrm{mg} \cdot \mathrm{m}^{-3}$ and even up to $>2 \mathrm{mg} \cdot \mathrm{m}^{-3}$ during an El Niño event and the Blob. Arroyo-Loranca et al. (2015) reported $\mathrm{Chl}_{\text {sat }}$ values of up to $1.9 \mathrm{mg} \cdot \mathrm{m}^{-3}$ in their TPE inshore zone during the 1997-1998 El Niño, and Torres-Moye and Álvarez-Borrego (1987) reported Chl values of up to $2 \mathrm{mg} \cdot \mathrm{m}^{-3}$ in surface water samples taken from the area off San Quintín Bay during the 1982-1983 El Niño.

During these warm events there was no apparent collapse of the central and southern CCS pelagic ecosystems. However, Torres-Moye and Álvarez-Borrego (1987) reported that in 1983 and 1984 the nanophytoplankton fraction dominated over the diatom and dinoflagellate species of microphytoplankton that normally prevail in these CCS coastal waters (Reid et al. 1978, Eppley et al. 1979). Furthermore, Putt and Prézelin (1985) reported that in 1983 more than 80\% of the phytoplankton biomass in the Santa Barbara Channel, California, was $<5 \mu \mathrm{m}$. These authors also reported dominant cyanobacteria $(0.5-1.5 \mu \mathrm{m})$. In spite of relatively high $\mathrm{Ch}_{\mathrm{sat}}$ values near the coast during a warm event, the ecosystem changes drastically from the base of the food chain.

SST showed clear seasonality both inshore and offshore, and it was clearly higher along both transects in 2014-2016 than in other years of our data set (Fig. 3). However, during the El Niño periods and the Blob, $\mathrm{Ch}_{\mathrm{sat}}$ and PP did not decrease in the offshore zone, likely because the small-sized phytoplankton (mostly cyanobacteria) typical of oceanic regions is adapted to oligotrophic conditions and its populations are relatively stable; most Chl variability in rich coastal waters is caused by large-sized phytoplankton (Yentsch and Phinney 1989).

Minimum SST, maxima $\mathrm{Ch}_{\mathrm{sat}}$, and maxima PP in the TPE inshore zone were $\sim 13{ }^{\circ} \mathrm{C}, 26 \mathrm{mg} \cdot \mathrm{m}^{-3}$, and $8.7 \mathrm{~g} \mathrm{C} \cdot \mathrm{m}^{-2} \cdot \mathrm{d}^{-1}$, respectively (Arroyo-Loranca et al. 2015). Each of these values was, accordingly, a little lower $\left(\sim 0.5^{\circ} \mathrm{C}\right)$ than the SST minima for TLJ and TSQB; between twice and two thirds the $\mathrm{Chl}_{\text {sat }}$ maxima on TLJ and TSQB, respectively; and similar or up to $34 \%$ higher than maxima PP on TLJ and TSQB, respectively. Ortiz-Ahumada et al. (in press) analyzed Aqua-MODIS de tiempo son muy cortas para que el análisis espectral muestre componentes interanuales claros de variancia, pero estos componentes se manifiestan con periodos superiores a 2 años (no ilustrado).

Como hubo un traslape de El Niño y el Blob, no es claro si ambos o únicamente el Blob causaron el decremento de $\mathrm{Chl}_{\text {sat }}$ y PP en las aguas costeras de TLJ y TBSQ durante la mayor parte de 2015. Después de septiembre de 2015, el efecto de El Niño fue la causa principal de los valores bajos de $\mathrm{Chl}_{\mathrm{sat}}$ en nuestra área de estudio. De acuerdo con Robinson (2016), el calentamiento reciente frente a Baja California ocurrió durante 2 periodos diferentes: el primer periodo ocurrió de mayo de 2014 a abril de 2015, cuando el aumento de TSM estuvo asociado a vientos costeros débiles que no estuvieron asociados a El Niño, el registro más largo y sostenido de anomalías negativas de vientos tomó lugar y la reducción del estrés del viento indicó surgencias costeras relativamente débiles; el segundo proceso de calentamiento ocurrió de septiembre a diciembre de 2015, cuando hubieron condiciones fuertes de El Niño (y claramente también en 2016 en TLJ).

El Niño 2009-2010 fue uno de los eventos del tipo CP más fuertes que han ocurrido en las últimas décadas (Lee y McPhaden 2010). Sin embargo, el impacto del evento de 2004 fue más fuerte que el de 2009-2010 en nuestras áreas de estudio, sobre todo en TBSQ. En la zona costera de TLJ el impacto del Blob de 2014 fue más fuerte que el de los eventos El Niño, y en la zona costera de TBSQ el mayor impacto fue el de El Niño 2004 (Figs. 4, 5). Sin embargo, los efectos de los eventos de calentamiento no fueron extremadamente fuertes en nuestras áreas de estudio ya que, a pesar de la disminución significativa de $\mathrm{Chl}_{\text {sat }}$ y PP, a menudo $\mathrm{Ch}_{\text {sat }}$ presentó valores $>1 \mathrm{mg} \cdot \mathrm{m}^{-3} \mathrm{y}$ hasta $>2 \mathrm{mg} \cdot \mathrm{m}^{-3}$ durante un evento El Niño y el Blob. Arroyo-Loranca et al. (2015) reportaron valores de $\mathrm{Chl}_{\mathrm{sat}}$ de hasta $1.9 \mathrm{mg} \cdot \mathrm{m}^{-3}$ durante El Niño de $1997-1998$ para la zona costera de su TPE, y Torres-Moye y Álvarez-Borrego (1987) reportaron valores de Chl de hasta $2 \mathrm{mg} \cdot \mathrm{m}^{-3}$ en muestras de agua superficial tomadas frente a la bahía San Quintín durante El Niño de 1982-1983.

Pareciera que, durante estos eventos cálidos, el ecosistema pelágico de las partes central y sur del SCC no colapsó. Sin embargo, Torres-Moye y Álvarez-Borrego (1987) reportaron que en 1983 y 1984 la fracción del nanofitoplancton dominó sobre las diatomeas y dinoflagelados del microfitoplancton que normalmente dominan en estas aguas costeras del SCC (Reid et al. 1978, Eppley et al. 1979). Además, Putt y Prézelin (1985) reportaron que en 1983 más del 80\% de la biomasa fitoplanctónica del canal de Santa Bárbara, California, midió $<5 \mu \mathrm{m}$. Estos últimos autores también reportaron que la población fue dominada por cianobacterias $(0.5-1.5 \mu \mathrm{m})$. A pesar de los valores de $\mathrm{Chl}_{\text {sat }}$ relativamente altos cerca de la costa durante un evento caliente, el ecosistema cambia drásticamente desde la base de la trama trófica.

La TSM mostró una variación estacional clara tanto en la zona costera como en la oceánica, y fue claramente más alta a lo largo de ambos transectos en 2014-2016 que 
data for 2 transects, one off Cabo San Lázaro (TCSLA) and the other off Cabo San Lucas (TCSLU), Baja California Sur, for the same study period as the one used in our study. The latter authors reported SST minima for their inshore zones that were $2.5^{\circ} \mathrm{C}$, in the case of TCSLA, and $\sim 6^{\circ} \mathrm{C}$, in the case of TCSLU, higher than the minima found for TLJ and TSQB. The $\mathrm{Chl}_{\text {sat }}$ maxima reported by Ortiz-Ahumada et al. (in press) were up to $9.8 \mathrm{mg} \cdot \mathrm{m}^{-3}$ for TCSLA and up to $6.5 \mathrm{mg} \cdot \mathrm{m}^{-3}$ for TCSLU, which are lower than maxima for TLJ; however, PP maxima for TCSLA and TCSLU were similar to PP maxima for TLJ. Chl ${ }_{\text {sat }}$ maxima were lower in the CCS region off Cabo San Lucas than on TLJ and TSQB because the coastal upwelling fertilizing effect decreased in the region off Cabo San Lucas. Bakun (1973) reported that his upwelling index decreased with latitude, from the area off southern California down to the area off the tip of the Baja California Peninsula.

Lara-Lara et al. (1980) performed hourly samplings at the mouth of San Quintín Bay during 18 d in June-July 1977 and reported an SST minimum of $\sim 11.5^{\circ} \mathrm{C}$ and $\mathrm{Chl}$ maxima (measured from water samples) of up to $15 \mathrm{mg} \cdot \mathrm{m}^{-3}$ (an isolated peak) but often of only $\sim 6 \mathrm{mg} \cdot \mathrm{m}^{-3}$, and with an average of $\sim 8 \mathrm{mg} \cdot \mathrm{m}^{-3}$ (considering only their data for flood flow, in other words, data for water coming into the bay from the adjacent oceanic area). Millán-Núñez et al. (1982) carried out a similar survey during $10 \mathrm{~d}$ in June-July 1979 and reported SST minima of $13.0^{\circ} \mathrm{C}$, and $\mathrm{Chl}$ maxima of up to $38 \mathrm{mg} \cdot \mathrm{m}^{-3}$ (an isolated peak), with a Chl maxima average of $\sim 9 \mathrm{mg} \cdot \mathrm{m}^{-3}$ (with flood flow). These $\mathrm{Chl}$ values indicate that the coastal $\mathrm{Ch}_{\text {sat }}$ maxima on TSQB, derived from monthly composites (up to $\sim 38 \mathrm{mg} \cdot \mathrm{m}^{-3}$, Table 2), were extremely high because some of the daily satellite values (within that month) were much higher. Caution should be exercised when analyzing absolute $\mathrm{Chl}_{\text {sat }}$ data for case II waters $\left(\mathrm{Chl}>1.5 \mathrm{mg} \cdot \mathrm{m}^{-3}\right)$, and trends in spatial and temporal changes should be considered. However, the $\mathrm{Chl}_{\text {sat }}$ time series consistently showed seasonal cycles and spatial changes that were in agreement with what is expected after the impact of physical phenomena such as water mass movements and the sequence of upwelling events (Santamaría-Del-Ángel et al. 1994).

Our inshore PP values for the first season are overestimated because the VGPM assumes a mixed euphotic zone with homogenous $\mathrm{Chl}$ vertical distribution. In nutrient-rich coastal waters, the Chl maximum is at the surface and values decrease with depth; thus, the assumption that there are no vertical changes in Chl produces PP overestimates. Phytoplankton production values $>4 \mathrm{~g} \mathrm{C} \cdot \mathrm{m}^{-2} \cdot \mathrm{d}^{-1}$ are not realistic and should be taken with caution by considering only the trends in spatial and temporal changes and not the absolute values (Álvarez-Molina et al. 2013, Arroyo-Loranca et al. 2015). According to Kahru and Mitchell (2002), even in the offshore waters of the CCS (100-300 km from the coast), satellite-derived PP overestimate ${ }^{14} \mathrm{C}$ measurements by $\sim 40 \%$.

PP data obtained from ${ }^{14} \mathrm{C}$ incubations are scarce, and it is very difficult to perform comparisons with satellite-derived data. In a strict sense, comparisons between PP data calculated en los otros años de nuestro conjunto de datos (Fig. 3). Sin embargo, durante los periodos de El Niño y el Blob, $\mathrm{Chl}_{\text {sat }} \mathrm{y}$ PP no disminuyeron en la zona oceánica. Esto podría deberse a que el fitoplancton pequeño (mayormente constituido por cianobacterias), típico de regiones oceánicas, está adaptado a condiciones oligotróficas y sus poblaciones son relativamente estables; la mayoría de la variabilidad de la $\mathrm{Chl}$ de aguas costeras ricas en nutrientes es causada por fitoplancton de tamaño grande (Yentsch y Phinney 1989).

En TPE, el mínimo de TSM y máximos de $\mathrm{Chl}_{\text {sat }}$ y PP para la zona costera fueron $\sim 13{ }^{\circ} \mathrm{C}, 26 \mathrm{mg} \cdot \mathrm{m}^{-3}$ y $8.7 \mathrm{~g} \mathrm{C} \cdot \mathrm{m}^{-2} \cdot \mathrm{d}^{-1}$ (Arroyo-Loranca et al. 2015). Cada uno de estos valores fue, respectivamente, un poco menor $\left(\sim 0.5^{\circ} \mathrm{C}\right)$ que los valores mínimos de TSM para TLJ y TBSQ; entre el doble y dos tercios los máximos de $\mathrm{Chl}_{\text {sat }}$ para TLJ y TBSQ, respectivamente; y similar o hasta un 34\% mayor que los máximos de PP para TLJ y TBSQ, respectivamente. Ortiz-Ahumada et al. (en prensa) analizaron datos del sensor Aqua-MODIS para 2 transectos, uno frente a cabo San Lázaro (TCSLA) y otro frente a cabo San Lucas (TCSLU), Baja California Sur, para el mismo periodo que el analizado en el presente estudio. Estos últimos autores reportaron mínimos de TSM para su zona costera hasta $2.5^{\circ} \mathrm{C}$, en el caso de TCSLA, y $\sim{ }^{\circ} \mathrm{C}$, en el caso de TCSLU, mayores que los mínimos de TLJ y TBSQ. Los máximos de $\mathrm{Chl}_{\text {sat }}$ reportados por Ortiz-Ahumada et al. (en prensa) fueron hasta $9.8 \mathrm{mg} \cdot \mathrm{m}^{-3}$ para TCSLA y hasta $6.5 \mathrm{mg} \cdot \mathrm{m}^{-3}$ para TCSLU, que son menores a los máximos para TLJ; sin embargo, los máximos de PP para TCSLA y TCSLU fueron similares a los máximos de PP para TLJ. Esto último se debe a la disminución del efecto fertilizador de las surgencias costeras en la zona del SCC frente a cabo San Lucas. Bakun (1973) reportó que su índice de surgencias decreció con la latitud, del área frente al sur de California hasta el área frente a la punta de la península de Baja California.

Lara-Lara et al. (1980) realizaron muestreos en la boca de la bahía San Quintín cada hora durante 18 d entre junio y julio de 1977 , y reportaron un mínimo de TSM de $\sim 11.5^{\circ} \mathrm{C}$, y máximos de Chl (medida en muestras de agua) de hasta $15 \mathrm{mg} \cdot \mathrm{m}^{-3}$ (un pico aislado) pero a menudo de solo $\sim 6 \mathrm{mg} \cdot \mathrm{m}^{-3}$, y con un promedio de $\sim 8 \mathrm{mg} \cdot \mathrm{m}^{-3}$ considerando solo sus datos para corrientes de marea en flujo, en otras palabras, solo los datos del agua entrando a la bahía desde la zona oceánica adyacente, en su periodo de muestreo. Millán-Núñez et al. (1982) realizaron un muestreo similar durante $10 \mathrm{~d}$, entre junio y julio de 1979 , y reportaron mínimos de TSM de $13{ }^{\circ} \mathrm{C}$ y máximos de Chl de $38 \mathrm{mg} \cdot \mathrm{m}^{-3}$ (un pico aislado), con un promedio de $\sim 9 \mathrm{mg} \cdot \mathrm{m}^{-3}$ (también con marea subiendo). Lo anterior indica que los valores máximos costeros de $\mathrm{Chl}_{\text {sat }}$ en TBSQ, obtenidos de composiciones mensuales (hasta $\sim 38 \mathrm{mg} \cdot \mathrm{m}^{-3}$, Tabla 2), fueron extremadamente altos ya que algunos valores diarios de satélite (dentro de ese mes) fueron mucho mayores. Se debe ser precavido con los valores absolutos de $\mathrm{Chl}_{\text {sat }}$ de aguas caso II $\left(\mathrm{Chl}>1.5 \mathrm{mg} \cdot \mathrm{m}^{-3}\right)$ y poner más atención a las tendencias de cambios espaciales y temporales. Sin embargo, las series de tiempo de $\mathrm{Chl}_{\text {sat }}$ fueron muy consistentes, puesto 
with VGPM and satellite imagery and PP estimates from ${ }^{14} \mathrm{C}$ incubations are not appropriate because the 2 data sets have completely different temporal and spatial scales: satellite-derived data are 1-month averages for $18 \times 18 \mathrm{~km}^{2}$ areas, while ${ }^{14} \mathrm{C}$ data are instantaneous point measurements (e.g., Balch and Byrne 1994, Kahru and Mitchell 2002). Gaxiola-Castro et al. (2010) obtained Chl fluorescence measurements and ${ }^{14} \mathrm{C}$-PP data during 4 cruises per year in the 1998-2007 period for the CCS off the Baja California Peninsula. Their sampling was carried out from the area off Ensenada $\left(\sim 31^{\circ} \mathrm{N}\right.$, CalCOFI line $100 ; \sim 100 \mathrm{~km}$ south from La Jolla) to the area off Cabo San Lázaro $\left(\sim 24^{\circ} \mathrm{N}, \mathrm{CalCOFI}\right.$ line 140). Gaxiola-Castro et al. (2010) found that integrated Chl was higher in spring and summer than in autumn and winter but that mean integrated ${ }^{14} \mathrm{C}$-PP was higher in autumn and winter; the PP data from these authors showed very large scattering (see their Fig. 7). Contrary to these findings, we found parallelism between $\mathrm{Chl}_{\text {sat }}$ and $\mathrm{PP}$, with the highest values in late spring and early summer. The large PP data scattering and larger values for winter, as opposed to those for spring-summer, reported by Gaxiola-Castro et al. (2010) were likely due to the patchy phytoplankton distribution and to the use of only 4 instantaneous point measurements per year per sampled location. Gaxiola-Castro et al. (2010) averaged their data set to obtain a mean distribution for their study area and reported PP values in milligrams of carbon per square meter per hour. Converting their average values to grams of carbon per square meter per day, their offshore values were $0.4-0.6 \mathrm{~g} \mathrm{C} \cdot \mathrm{m}^{-2} \cdot \mathrm{d}^{-1}$, which are in agreement with our PP values for the offshore zone. Their average values for the inshore area close to San Quintín Bay fluctuated between 1.0 and $1.5 \mathrm{~g} \mathrm{C} \cdot \mathrm{m}^{-2} \cdot \mathrm{d}^{-1}$, and these values are not in agreement with the range for our data $\left(0.3-6.4 \mathrm{~g} \mathrm{C} \cdot \mathrm{m}^{-2} \cdot \mathrm{d}^{-1}\right)$ because our range includes PP overestimates for waters with high $\mathrm{Chl}_{\text {sat }}$.

\section{ACKNOWLedgments}

The first author was granted a scholarship by the National Council of Science and Technology (CONACYT, Mexico) for his graduate studies at CICESE. We thank the National Aeronautics and Space Administration (NASA, USA) for providing the imagery and the software for processing the data, and the National Oceanic and Atmospheric Administration (NOAA, USA) for providing the ENSO index, and the imagery with the SST anomalies. Francisco Ponce helped with the art work.

\section{REFERENCES}

Álvarez-Borrego J, Álvarez-Borrego S. 1982. Temporal and spatial variability of temperature in two coastal lagoons. CalCOFI Rep. 23: 188-197.

Álvarez-Borrego S. 2004. Nutrient and phytoplankton dynamics in a coastal lagoon strongly affected by coastal upwelling = Dinámica de nutrientes y fitoplancton en una laguna costera fuertemente afectada por surgencias costeras. Cienc. Mar. 30(1A): 1-19. que sus ciclos estacionales y su variación espacial se comportaron muy de acuerdo a lo esperado por el impacto de fenómenos físicos tales como el movimiento de masas de agua y la secuencia de eventos de surgencia (Santamaría-Del-Ángel et al. 1994).

Nuestros valores de PP para las aguas de la zona costera durante la primera temporada están sobrestimados porque el VGPM supone una zona eufótica bien mezclada y una distribución vertical homogénea de Chl. En las aguas costeras ricas en nutrientes el máximo de Chl está en la superficie y los valores de Chl decrecen con la profundidad, y el suponer que no hay cambios verticales de clorofila produce sobrestimaciones de PP. Los valores de PP $>4 \mathrm{~g} \mathrm{C} \cdot \mathrm{m}^{-2} \cdot \mathrm{d}^{-1}$ no son realistas $\mathrm{y}$ deben ser tomados con precaución considerando solamente las tendencias de cambio espacial y temporal y no los valores absolutos (Álvarez-Molina et al. 2013, Arroyo-Loranca et al. 2015). De acuerdo con Kahru y Mitchell (2002), aún en las aguas oceánicas del SCC (100-300 km de la costa) los datos de PP derivados de satélite sobrestiman los obtenidos con incubaciones con ${ }^{14} \mathrm{C}$ en un $\sim 40 \%$.

Los datos de PP obtenidos mediante muestreos de agua e incubaciones con ${ }^{14} \mathrm{C}$ son muy escasos y es muy difícil realizar comparaciones con datos derivados de satélite. En el sentido estricto, las comparaciones entre los datos de PP calculados con el VGPM e imágenes de satélite y las estimaciones de PP obtenidas mediante incubaciones con ${ }^{14} \mathrm{C}$ no son apropiadas porque los 2 conjuntos de datos tienen escalas temporales y espaciales totalmente diferentes: los datos derivados de satélite son promedios de un mes para áreas de $18 \times 18 \mathrm{~km}^{2}$, mientras que los datos de ${ }^{14} \mathrm{C}$ son mediciones puntuales instantáneas (e.g., Balch y Byrne 1994, Kahru y Mitchell 2002). Gaxiola-Castro et al. (2010) obtuvieron datos de Chl medida por fluorescencia y datos de PP estimados mediante el método ${ }^{14} \mathrm{C}$ durante 4 cruceros por año en el periodo 1998-2007 para el SCC frente a la península de Baja California. Sus muestreos se realizaron del área frente a Ensenada $\left(\sim 31^{\circ} \mathrm{N}\right.$, línea CalCOFI $100 ; \sim 100 \mathrm{~km}$ al sur de La Jolla) hasta el área frente a cabo San Lázaro $\left(\sim 24^{\circ} \mathrm{N}\right.$, línea CalCOFI 140). Gaxiola-Castro et al. (2010) reportaron que la $\mathrm{Chl}$ integrada era más alta en primavera y verano que en otoño e invierno pero que la media de PP integrada estimada mediante el método ${ }^{14} \mathrm{C}$ era más alta en otoño e invierno; sus datos de PP muestran una gran dispersión (ver su Fig. 7). Esto contrasta con lo que aquí se reporta, ya que nosotros encontramos paralelismo entre $\mathrm{Chl}_{\text {sat }}$ y PP, con valores más altos a finales de primavera y principios de verano. Posiblemente, la gran dispersión de datos de PP y los valores más altos de invierno, en comparación con los de primavera y verano, que encontraron Gaxiola-Castro et al. (2010) se debieron a la distribución del fitoplancton en forma de manchas y al uso de solo 4 mediciones instantáneas puntuales por año y por localidad de muestreo. Gaxiola-Castro et al. (2010) promediaron su conjunto de datos para generar una distribución media para su área de estudio y reportaron valores de PP en miligramos de carbono por metro cuadrado por hora. Al transformar sus 
Álvarez-Molina LL, Álvarez-Borrego S, Lara-Lara JR, Marinone SG. 2013. Annual and semiannual variations of phytoplankton biomass and production in the central Gulf of California estimated from satellite data = Variaciones anual y semianual de la biomasa y producción fitoplanctónica en el golfo de California central estimadas de datos de satélite. Cienc. Mar. 39(2): $217-230$

Arroyo-Loranca RG, Álvarez-Borrego S, Ortiz-Figueroa M, LE Calderón-Aguilera. 2015. Spatial and temporal variation of satellite-derived phytoplankton biomass and production in the California Current System off Punta Eugenia, during 1997-2012. Hidrobiológica 25(3): 321-334.

Bakun A. 1973. Coastal upwelling indices, west coast of North America 1946-71. NOAA Tech. Rep. NMFS SSRF-671. US Dept. Commerce, Seattle, WA.

Balch WM, Byrne CF. 1994. Factors affecting the estimate of primary production from space. J. Geophys. Res. 99(C4): 75557570. http://dx.doi.org/10.1029/93JC03091

Behrenfeld MJ, Falkowsky PG. 1997. Photosynthetic rates derived from satellite-based chlorophyll concentration. Limnol. Oceanogr. 42(1): 1-20. http://dx.doi.org/10.4319/1o.1997.42.1.0001

Bond NA, Cronin MF, Freeland H, Mantua N. 2015. Causes and impacts of the 2014 warm anomaly in the NE Pacific. Geophys. Res. Lett. 42(9): 3414-3420. http://dx.doi.org/10.1002/2015GL063306

Coronado-Álvarez LLA, Álvarez-Borrego S, Lara-Lara JR, SolanaArellano E, Hernández-Ayón JM, Zirino A. 2017. Temporal variations of water $\mathrm{pCO}_{2}$ and the air-water $\mathrm{CO}_{2}$ flux at a coastal location in the southern California Current System: diurnal to interannual scales $=$ Variaciones temporales de $\mathrm{pCO}_{2}$ del agua y flujos aire-agua de $\mathrm{CO}_{2}$ en una localidad costera en el sur del Sistema de la Corriente de California: de la escala diurna a la interanual. Cienc. Mar. 43(3): 137-156.

http://dx.doi.org/10.7773/cm.v43i3.2707

Dorman CE. 1982. Winds between San Diego and San Clemente Island. J. Geophys. Res. 87(C12): 9636-9646. http://dx.doi.org/10.1029/Jc087ic12p09636

Durazo R. 2015. Seasonality of the transitional region of the California Current System off Baja California. J. Geophys. Res. 120(2): 1173-1196. http://dx.doi.org/10.1002/2014JC010405

Durazo R, Gaxiola-Castro G, Lavaniegos B, Castro-Valdez R, Gómez-Valdés J, Mascarenhas Jr. ADS. 2005. Oceanographic conditions west of the Baja California coast, 2002-2003: A weak El Niño and subarctic water enhancement $=$ Condiciones oceanográficas frente a la costa occidental de Baja California, 2002-2003: Influencia de un El Niño débil y del incremento de agua subártica. Cienc. Mar. 31(3): 537-552.

Durazo R, Ramírez-Manguilar AR, Miranda LE, Soto-Mardones LA. 2010. Climatología de variables hidrográficas. In: GaxiolaCastro G, Durazo R (eds.), Dinámica del Ecosistema Pelágico frente a Baja California, 1997-2007: Diez años de Investigaciones Mexicanas de la Corriente de California. Secretaría de Medio Ambiente y Recursos Naturales, Mexico City, pp. 25-58.

Eppley RW, Renger EH, Harrison WG. 1979. Nitrate and phytoplankton production in southern California coastal waters. Limnol. Oceanogr. 24(3): 483-494. http://dx.doi.org/10.4319/1o.1979.24.3.0483

Eppley RW, Stewart E, Abbott MR, Heyman U. 1985. Estimating ocean primary productivity from satellite chlorophyll. Introduction to regional differences and statistics for the Southern California Bight. J. Plankton Res. 7(1): 57-70. https://doi.org/10.1093/plankt/7.1.57

Espinosa-Carreon TL, Strub PT, Beier E, Ocampo-Torres F, GaxiolaCastro G. 2004. Seasonal and interannual variability of satellitederived chlorophyll pigment, surface height, and temperature off valores promedio para la zona oceánica a gramos de carbono por metro cuadrado por día, sus valores resultan en $0.4-0.6 \mathrm{~g}$ $\mathrm{C} \cdot \mathrm{m}^{-2} \cdot \mathrm{d}^{-1}$, los cuales concuerdan con nuestros valores de PP obtenidos para esta zona. Sus valores promedio para la zona costera cercana a la bahía San Quintín fluctuaron entre 1.0 y $1.5 \mathrm{~g} \mathrm{C} \cdot \mathrm{m}^{-2} \cdot \mathrm{d}^{-1}$, y estos valores no concuerdan con el rango de nuestros valores $\left(0.3-6.4 \mathrm{~g} \mathrm{C} \cdot \mathrm{m}^{-2} \cdot \mathrm{d} \cdot 1\right)$ porque nuestro rango incluye sobrestimaciones de PP para las aguas de alta $\mathrm{Chl}_{\text {sat }}$.

\section{Agradecimientos}

El primer autor recibió una beca de posgrado del Consejo Nacional de Ciencia y Tecnología (CONACYT, México) para estudiar en CICESE. Agradecemos a la NASA (EUA) el proveer las imágenes de satélite y la programática para el procesado de los datos, y a la National Oceanic and Atmospheric Administration (NOAA, EUA) el proveer las imágenes de anomalías de TSM y el índice del ENOS. Francisco Ponce nos ayudó en la elaboración de las figuras.

Baja California. J. Geophys. Res. 109(C3039): 1-20. http://dx.doi.org/10.1029/2003JC002105

Fargion GS. 1989. Physical and biological patterns during El Niño and non-El Niño episodes in the California Current. Dissertation, University of California San Diego, San Diego, CA, 145 pp.

Fargion GS, McGowan JA, Stewart RH. 1993. Seasonality of chlorophyll concentrations in the California Current: A comparison of two methods. CalCOFI Rep. 34: 35-50.

Gaxiola-Castro G, Álvarez-Borrego S. 1991. Relative assimilation numbers of phytoplankton across a seasonally recurring front in the California Current off Ensenada. CalCOFI Rep. 32: 91-96.

Gaxiola-Castro G, Cepeda-Morales J, Nájera-Martínez S, EspinosaCarreón LT, De-La-Cruz-Orozco ME, Sosa-Avalos R, AguirreHernández E, Cantú-Ontiveros JP. 2010. Biomasa y producción del fitoplancton. In: Gaxiola-Castro G, Durazo R (eds.), Dinámica del Ecosistema Pelágico frente a Baja California 1997-2007: Diez años de Investigaciones Mexicanas de la Corriente de California. Secretaría de Medio Ambiente y Recursos Naturales, Mexico City, pp. 59-85.

Gentemann CL, Fewings MR, García-Reyes M. 2017. Satellite sea surface temperatures along the West Coast of the United States during the 2014-2016 northeast Pacific marine heat wave, Geophys. Res. Lett. 44: 312-319. https://doi:10.1002/2016GL071039.

Haury LR, Venrick E, Fey CL, McGowan JA, Neil PP. 1993. The Ensenada front: July 1985. CalCOFI Rep. 34: 69-88.

Henson SA, Thomas AC. 2007a. Phytoplankton scales of variability in the California Current System: 2. Latitudinal variability. J. Geophys. Res. 112(C7): C07018.

Henson SA, Thomas AC. 2007b. Interannual variability in timing of bloom initiation in the California Current System. J. Geophys. Res. 112(C8): C08007. http://dx.doi.org/10.1029/2006JC003960

Kahru M, Mitchell BG. 2000. Influence of the 1997-98 El Niño on the surface chlorophyll in the California Current. Geophys. Res. Lett. 27(18): 2937-2940. http://dx.doi.org/10.1029/2000GL011486

Kahru M, Mitchell BG. 2002. Influence of the El Niño-La Niña cycle on satellite-derived primary production in the California Current. Geophys. Res. Lett. 29(17): 27-1-27-4. http://dx.doi.org/10.1029/2002GL014963 
Lara-Lara JR, Álvarez-Borrego S, Small LF. 1980. Variability and tidal exchange of ecological properties in a costal lagoon. Estuar. Coast. Mar. Sci. 11(6): 613-637.

http://dx.doi.org/10.1016/S0302-3524(80)80014-4

Lara-Lara JR, Valdéz-Holguín JE, Jiménez-Pérez LC. 1984. Plankton studies in the Gulf of California during the 1982-83 El Niño. Trop. Ocean-Atmos. Newsl. 28: 16-17.

Lee T, McPhaden MJ. 2010. Increasing intensity of El Niño in the central-equatorial Pacific. Geophys. Res. Lett. 37(14). L14603. http://dx.doi.org/10.1029/2010GL044007

Lynn RJ. 1967. Seasonal variation of temperature and salinity at 10 meters in the California Current. CalCOFI Rep. 11: 157-186.

Lynn RJ, Bliss KA, Eber LE. 1982. Vertical and horizontal distributions of seasonal mean temperature, salinity, sigma-t, stability, dynamic height, oxygen and oxygen saturation in the California Current, 1950-1978. CalCOFI Atlas 30.

Lynn RJ, Collins C, Mantyla AW, Schwing FB, Baumgartner T, Hayward TL, Murphree T, Sakuma KM, Garcia J, Hyrenbach KD, Shankle A, Tegner MJ. 1998. The state of the California current, 1997-1998: Transition to El Niño conditions. CalCOFI Rep. 39: 25-49.

Lynn RJ, Simpson JJ. 1987. The California Currents System: The seasonal variability of its physical characteristics. J. Geophys. Res. 92(C12): 12947-12966. http://dx.doi.org/10.1029/JC092iC12p12947

Michaelsen J, Zhang X, Smith RC. 1988. Variability of pigment biomass in the California Current as determined by satellite imagery, 2. Temporal variability. J. Geophys. Res. 93(D9): 10883-10896.

Millán-Nuñez R, Álvarez-Borrego S, Nelson DM. 1982. Effects of physical phenomena on the distribution of nutrients and phytoplankton productivity in a coastal lagoon. Estuar. Coast. Shelf Sci. 15(3): 317-335. http://dx.doi.org/10.1016/0272-7714(82)90066-X

Münchow A. 2000. Wind stress curl forcing of the coastal ocean near Point Conception, California. J. Phys. Oceanogr. 30(6): 12651280.

http://dx.doi.org/10.1175/1520-0485(2000)030<1265:WSCFOT $>2.0 . \mathrm{CO} ; 2$

[NASA] National Aeronautical and Space Administration. 2017. Ocean Color web [accessed January 2015-February 2017]. http://oceancolor.gsfc.nasa.gov/.

[NOAA] National Oceanic and Atmospheric Administration. 2017a. Office of satellite and products operations. National environmental satellite, data, and information services [accessed January 2017]. http://www. ospo.noaa.gov.

[NOAA] National Oceanic and Atmospheric Administration. 2017b. MEI Index [accessed January 2017]. http://www.esrl.noaa.gov/ psd/enso/mei/table.html.

Ortiz-Ahumada JC, Álvarez-Borrego S, Gómez-Valdez J. 2017. Effects of seasonal and interannual events on satellite derived phytoplankton biomass and production in the southernmost part of the California Current System, in 2002-2016. Cienc. Mar. In press.

[OSU] Oregon State University. 2017. Ocean Net Primary Productivity of Oregon State University [accessed January 2015-February 2017]. http://www.science.oregonstate.edu/ocean.productivity/ index.php.

Peláez J, McGowan JA. 1986. Phytoplankton pigment patterns in the California Current as determined by satellite. Limnol. Oceanogr. 31(5): 927-950.

http://dx.doi.org/10.4319/1o.1986.31.5.0927
Pérez-Brunius P, López M, Parés-Sierra A, Pineda J. 2007. Comparison of upwelling indices off Baja California derived from three different wind data sources. CalCOFI Rep. 48: 204-214.

Putt M, Prézelin BB. 1985. Observations of diel patterns of photosynthesis in cyanobacteria and nanoplankton in the Santa Barbara Channel during "El Niño". J. Plankton Res. 7(6): 779-790. https://doi.org/10.1093/plankt/7.6.779

Reid JL. 1962. On the circulation, phosphate-phosphorus content, and zooplankton volumes in the upper part of the Pacific Ocean. Limnol. Oceanogr. 7(3): 287-306. http://dx.doi.org/10.4319/lo.1962.7.3.0287

Reid JL. 1988. Physical Oceanography. CalCOFI Rep. 29: 42-65.

Reid FM, Stewart E, Eppley RW, Goodman D. 1978. Spatial distribution of phytoplankton species in chlorophyll maximum layers off southern California. Limnol. Occanogr. 23(2): 219-226. http://dx.doi.org/10.4319/1o.1978.23.2.0219

Robinson CJ. 2016. Evolution of the 2014-2015 sea surface temperature warming in the central west coast of Baja California, Mexico, recorded by remote sensing. Geophys. Res. Lett. 43(13): 7066-7071. http://dx.doi.org/10.1002/2016GL069356

Santamaría-del-Ángel E, Álvarez-Borrego S, Millán-Nuñez R, Müller-Karger FE. 1999. Sobre el efecto de las surgencias de verano en la biomasa fitoplanctónica del Golfo de California. Rev. Soc. Mex. Hist. Nat. 49: 207-212.

Santamaría-del-Ángel E, Álvarez-Borrego S, Müller-Karger FE. 1994. Gulf of California biogeographic regions based on coastal zone color scanner imagery. J. Geophys. Res. 99(C4): 74117421. http://dx.doi.org/10.1029/93JC02154

Santamaría-del-Ángel E, Millán-Núñez R, González-Silvera A, Muller-Karger FE. 2002. The color signature of the Ensenada Front and its seasonal and interannual variability. CalCOFI Rep. 43: $155-161$.

Soto-Mardones L, Parés-Sierra A, García J, Durazo R, Hormazabal S. 2004. Analysis of the mesoscale structure in the IMECOCAL region (off Baja California) from hydrographic, ADCP and altimetry data. Deep-Sea Res. 51(6-9): 785-798. http://dx.doi.org/10.1016/j.dsr2.2004.05.024

Strub PT, Kosro PM, Huyer A. 1991. The nature of the cold filaments in the California Current System. J. Geophys. Res. 96(C8): 14743-14768.

Thomas AC, Strub PT. 1990. Seasonal and interannual variability of pigment concentrations across a California Current frontal zone. J. Geophys. Res. 95(C8): 13023-13042. http://dx.doi.org/10.1029/JC095iC08p13023

Torres-Moye G, Álvarez-Borrego S. 1987. Effects of the 1984 El Niño on the summer phytoplankton of a Baja California upwelling zone. J. Geophys. Res. 92(C13): 14383-14386.

Winant CD, Dorman CE. 1997. Seasonal patterns of Surface wind stress and heat flux over the Southern California Bight. J. Geophys. Res. 102(C3): 5641-5653. http://dx.doi.org/10.1029/96JC02801

Yentsch CS, Phinney DA. 1989. A bridge between ocean optics and microbial ecology. Limnol. Oceanogr. 34(8): 1694-1705.

Zaba KD, Rudnick DL. 2016. The 2014-2015 warming anomaly in the Southern California Current System observed by underwater gliders. Geophys. Res. Lett. 43(3): 1241-1248. http://dx.doi.org/10.1002/2015GL067550

Received March 2017, Accepted August 2017. 